Eskişehir Osmangazi Üniversitesi ïBF Dergisi

Aralık 2020, C. 15, S. 3, $1095-1118$

Başvuru : :18.12.2019

Kabul : :17.04.2020

\title{
Türkiye'de Uluslararası İktisadi Dalgalanmaların Yayılma Etkisi ve Konjonktür Karşıtı Para Politikası ${ }^{1}$
}

\author{
Can Karabıyık ${ }^{2}$
}

Türkiye'de Uluslararası iktisadi Dalgalanmaların Yayılma Etkisi ve Konjonktür Karşıtı Para Politikası

Öz

Bu çalışmanın ilk aşamasında Diebold ve Yılmaz (2009) Yayılma Endeksi yöntemi ile iktisadi dalgalanmaların uluslararası yayılımı incelenmiştir. Çalışmanın ikinci aşamasında ise para politikasının durum asimetrisi Markov Rejim Değişimi yöntemi ile test edilmiştir. Yayılım Endeksi bulgularına göre, Türkiye'yi etkileyen şokların \%48'i dış kaynaklıdır. Türkiye'de meydana gelen iktisadi dalgalanmaların $\% 12,5^{\prime}$ i Güney Kore'den, \%8,4'ü ABD'den, \%6,4'ü Japonya'dan, \%4,5'i Yunanistan'dan ve \%3,2'si ise İspanya ekonomisinden kaynaklanmaktadır. Bu sonuçlara göre, bu ülkelerin iktisadi koşulları, Türkiye ekonomisi için bir öncü gösterge niteliğindedir. Markov Rejim Değişimi modeli bulguları ise, Türkiye ekonomisinin büyüme rejiminde ortalama \%1,82 büyüdüğünü, daralma rejiminde ortalama \%3,38 küçüldüğünü ve döviz kurundaki artışların büyümeyi yavaşlattığını göstermektedir. Son olarak TCMB'nin, genişleme rejiminde reel etki meydana getirebildiği ancak durgunluk ile mücadelede reel etki yaratamadığına dair ekonometrik kanıtlar elde edilmiştir.

Anahtar Kelimeler: Yayılma Etkisi, Konjonktür Karşıtı Para Politikası, Para Politikası Asimetrisi, Doğrusal Olmayan Zaman Serileri
International Business Cycle Spillover Effects and Counter-Cyclical Monetary Policy

\begin{abstract}
In the first phase of this study the international spillover of economic fluctuations is investigated by Diebold and Yılmaz (2009) Spillover Index method. In the second stage of the study, the state asymmetry of the monetary policy has been tested by Markov Regime Switching method. According to the Spillover Index findings, $48 \%$ of economic shocks affecting the Turkey caused by external shocks. The economic fluctuations that occurred in Turkey are originated $12,5 \%$ from South Korea, $8.4 \%$ from US, $6.4 \%$ from Japan, $4.5 \%$ from Greece and 3.2\% from the Spanish Economy. According to these results, the economic conditions of these countries are leading indicators for the Turkish Economy. Markov Regime Switching model findings show that Turkish Economy grows $1.82 \%$ on an average in the expansion, shrinks $3.38 \%$ on an average in the contraction and an increase in the exchange rate slows the economic growth in Turkey. Finally obtained econometric evidence shows that CBRT can bring real effect in expansion regime but not create real impact in the fight against recession.
\end{abstract}

Keywords: Spillover Effect, Counter-cyclical Monetary Policy, Monetary Policy Asymmetry, Non-Linear Time Series

\section{Giriş}

1900 'lü yılların son çeyreğinden günümüze küresel iktisadi sistemin genel görüntüsü, gelişen bilişim ve lojistik teknolojilerinin de yardımıyla büyük oranda değişmiştir. Bu değişim, ülkelerin aralarındaki ticari ve finansal bağlantıların hızla çoğalmasına sebep olmuştur. Gelişmekte olan piyasa ekonomileri küresel iktisadi aktörler haline gelirlerken, dış ticaret vasıtasıyla uluslararası bir ağ oluşmuş ve uluslararası bağlılık günden güne artmıştır. Bütün bu gelişmeler, 2009 'da yaşanan küresel finansal krizin neticeleri ve bu krizin uluslararası yayılma etkileri ile birlikte, ülkelerin iktisadi dalgalanmalarının birlikte hareket ettiği yönündeki savlar üzerinde güçlü bir tartışma yaratmıştır.

\footnotetext{
${ }^{1}$ Bu çalışma Manisa Celal Bayar Üniversitesi Sosyal Bilimler Enstitüsü İktisat Anabilim Dalı’nda Can Karabıyık tarafından "Türkiye'de Uluslararası İktisadi Dalgalanmaların Yayılma Etkisi ve Para Politikası Asimetrisi" ismiyle tamamlanarak 27.06.2019 tarihinde savunulan doktora tezinden türetilmiştir.

${ }^{2}$ Arş. Gör. Dr., Manisa Celal Bayar Üniversitesi, iiBF, İktisat Bölümü. can.karabiyik@cbu.edu.tr, Yazar ORCID bilgisi: https://orcid.org/0000-0002-7255-7946
} 
Ülkelerin güçlü finansal ve ticari bütünleşme içerisinde olmaları, benzer para ve maliye politikaları yürütmeleri veya küresel ölçekte gerçekleşen faiz oranı ya da petrol fiyatı şokları ülkelere özgü şokların uluslararası yayılımına neden olabilmektedir (Akın, 2007: 2). Dünyadaki karşılıklı iktisadi bağımlılık olarak da nitelendirilebilecek olan küresel şoklar sonucunda, herhangi bir ülkede meydana gelebilecek bir gelişme, ülkelerin dışa açıklık derecesine bağlı olarak ödemeler dengesi aracılığıyla dünyanın geri kalan bölgelerine kolaylıkla yayılabilmektedir (Dellas, 1986: 381). Küresel şokların dünya ekonomisini yönlendirmede baskın rolü olmasına rağmen, ülkelere özgü ve bölgesel şoklar da iktisadi dalgalanmaların uluslararası yayılımını etkileyebilmektedir (Schneider ve Fenz, 2011: 2777). Son dönemlerde artan küreselleşme, bir yandan ülkelerin birbirlerine olan karşıııkı bağımlıı̆ı̆ını arttırmakta, bir yandan da her bir ülkenin kendisine has olan iktisadi dalgalarının birbirlerine yakınsamasına neden olabilmektedir. Artan dış ticaret açıklığı ve sermaye hareketleri sonucunda ülkeler dışsal şoklara karşı hassasiyet kazanarak kırılganlaşmaktadır. Bu kırılganlık iktisadi dalgaların birbirlerine yakınsaması sonucunda çeşitli kanallar vasıtasıyla ülkeden ülkeye sıçrayarak küresel krizleri tetikleyebilmektedir.

İktisadi dalgalanma hareketlerinin ülkeler arasındaki yayılma etkisi iktisat yazınında büyük ilgi görmektedir. Ülkelerin mevcut durumunda iktisadi dalgalanmaların hangi aşamasında olduğunun öğrenilmesi, etkin ve başarılı bir politika geliştirilebilmesi açısından büyük önem taşıdığı gibi, iktisadi dalgalanmaların yayılma etkisi de Türkiye gibi yükselen piyasa ekonomilerinin gidişatı hakkında önemli bilgiler verebilecektir. İktisat yazınında iktisadi dalgalanmalardaki karşılıklı bağımlılık ve uluslararası iktisadi dalgalanmaların birlikte hareket ettiği vurgulanarak ABD gibi büyük ekonomilerde ortaya çıkan şokların dünyanın geri kalanında yıkıcı etkiler yaratabildiği iddia edilmektedir. Ülkeler kendi iç sorunlarını çözmeye yoğunlaşarak yabancı ekonomilerden gelebilecek şoklara karşı önlem almakta geciktiği zaman dış dünyadan gelen bir dalganın etkisinin daha yıkıcı bir hal alabilmektedir.

İki adet ampirik araştırmanın yer aldığı bu çalışmanın ilk bölümünde, iktisadi dalgalanmaların yayılımı dünyanın en gelişmiş ekonomilerini de içeren 24 ülke ${ }^{3}$ özelinde incelenmektedir. Uluslararası iktisadi dalgalanmaların yayılımı literatüründe yapılmış olan çalışmalar Tablo 1'de özetlenmiştir:

Tablo 1: Uluslararası Iktisadi Dalgalanmaların Yayılımı Yazın Taraması

\begin{tabular}{llllll}
\hline Yazar & Dönem & Ülke/Bölge & Değişkenler & Yöntem & Sonuçlar \\
\hline $\begin{array}{l}\text { Gregory vd. } \\
\text { (1997) }\end{array}$ & 1970-1993 & G-7 Ülkeleri & $\begin{array}{l}\text { Çıktı, tüketim ve } \\
\text { yatırım }\end{array}$ & $\begin{array}{l}\text { Kalman filtresi ve } \\
\text { dinamik faktör } \\
\text { analizi }\end{array}$ & Yayılım mevcut \\
\hline $\begin{array}{l}\text { Gallo ve Ertur } \\
\text { (2003) }\end{array}$ & $1980-1995$ & $\begin{array}{l}\text { 138 Avrupa } \\
\text { Bölgesi }\end{array}$ & Kişi başı gelir & $\begin{array}{l}\text { Açıklayıcı } \\
\text { mekânsal veri } \\
\text { analizi }\end{array}$ & Yakınsama mevcut \\
\hline $\begin{array}{l}\text { Doyle ve Faust } \\
\text { (2005) }\end{array}$ & $1960-2002$ & G-7 ülkeleri & Milli gelir & Korelasyon analizi & Korelasyon yok \\
\hline $\begin{array}{l}\text { Kose vd. (2008) } \\
\text { 1960-2005 }\end{array}$ & 106 Ülke & $\begin{array}{l}\text { Çıktı, tüketim, } \\
\text { yatırım. }\end{array}$ & $\begin{array}{l}\text { Dinamik faktör } \\
\text { analizi }\end{array}$ & Yakınsama yoktur. \\
\hline $\begin{array}{l}\text { Diebold ve } \\
\text { Yılmaz (2009) }\end{array}$ & $1990-2009$ & 19 Ülke & $\begin{array}{l}\text { Hisse senedi fi- } \\
\text { yat endeksi }\end{array}$ & $\begin{array}{l}\text { Diebold-Yılmaz } \\
\text { Yayılma Endeksi }\end{array}$ & $\begin{array}{l}\text { Yayılım artan } \\
\text { trende sahiptir ve }\end{array}$ \\
\hline
\end{tabular}

${ }^{3}$ ABD, Almanya, Avusturya, Belçika, Brezilya, Danimarka, Fransa, Hollanda, İngiltere, İrlanda, İspanya, İsrail, İsveç, İtalya, Kanada, Kore, Lüksemburg, Macaristan, Meksika, Norveç, Japonya, Portekiz, Türkiye, Yunanistan. 


\begin{tabular}{|c|c|c|c|c|c|}
\hline & & & & & $\begin{array}{l}\text { kriz dönemlerinde } \\
\text { yükselmektedir }\end{array}$ \\
\hline Yılmaz (2009) & $1958-2009$ & G-6 Ülkeleri & $\begin{array}{l}\text { Endüstriyel üre- } \\
\text { tim endeksi }\end{array}$ & $\begin{array}{l}\text { Diebold-Yılmaz } \\
\text { Yayılma Endeksi }\end{array}$ & $\begin{array}{l}\text { Yayılım mevcuttur } \\
\text { ve kriz dönemle- } \\
\text { rinde yükselmekte- } \\
\text { dir }\end{array}$ \\
\hline $\begin{array}{l}\text { Bayoumi ve Bui } \\
(2010)\end{array}$ & $1970-2007$ & $\begin{array}{l}A B D \text {, İngil- } \\
\text { tere, Ja- } \\
\text { ponya, } A B \\
\text { gibi gelişmiş } \\
\text { ekonomiler }\end{array}$ & Reel GSYiH & $\begin{array}{l}\text { Yapısal vektör oto } \\
\text { regresyon }\end{array}$ & Yayılım mevcuttur \\
\hline $\begin{array}{l}\text { Fidrmuc vd. } \\
\text { (2012) }\end{array}$ & $1990-2008$ & $\begin{array}{l}\text { OECD Ülke- } \\
\text { leri }\end{array}$ & $\begin{array}{l}\text { Dış ticaret, fi- } \\
\text { nansal bütün- } \\
\text { leşme ve uzman- } \\
\text { laşma }\end{array}$ & $\begin{array}{l}\text { Dinamik korelas- } \\
\text { yon }\end{array}$ & Yayılım mevcuttur \\
\hline $\begin{array}{l}\text { Diebold ve } \\
\text { Yılmaz (2013) }\end{array}$ & $1960-2010$ & $\begin{array}{l}\text { İngiltere, } \\
\text { Fransa, Al- } \\
\text { manya, } \\
\text { İtalya, Ja- } \\
\text { ponya ve } \\
\text { ABD }\end{array}$ & $\begin{array}{l}\text { Endüstriyel üre- } \\
\text { tim endeksi }\end{array}$ & $\begin{array}{l}\text { Diebold-Yılmaz } \\
\text { Yayılma Endeksi }\end{array}$ & Yayılım mevcuttur \\
\hline $\begin{array}{l}\text { Antonakakis ve } \\
\text { Badinger (2014) }\end{array}$ & $1870-2013$ & 27 Ülke & $\begin{array}{l}\text { Kredi büyümesi } \\
\text { ve çıktı büyü- } \\
\text { mesi }\end{array}$ & $\begin{array}{l}\text { Diebold-Yılmaz } \\
\text { Yayılma Endeksi }\end{array}$ & Yayılım mevcuttur \\
\hline $\begin{array}{l}\text { Antonakakis vd. } \\
\text { (2015) }\end{array}$ & $1957-2012$ & G-7 ülkeleri & $\begin{array}{l}\text { Kredi büyümesi } \\
\text { ve çıktı büyü- } \\
\text { mesi }\end{array}$ & $\begin{array}{l}\text { Diebold-Yılmaz } \\
\text { Yayılma Endeksi }\end{array}$ & $\begin{array}{l}\text { Yayılım mevcuttur } \\
\text { ve kriz dönemle- } \\
\text { rinde yükselmekte- } \\
\text { dir. }\end{array}$ \\
\hline $\begin{array}{l}\text { Mumtaz ve } \\
\text { Theodoridis } \\
\text { (2015) }\end{array}$ & $1975-2011$ & $\begin{array}{l}A B D \text { ve İngil- } \\
\text { tere }\end{array}$ & GSYIH ve TÜFE & $\begin{array}{l}\text { Yapisal vektör } \\
\text { otoregresif mo- } \\
\text { deli }\end{array}$ & Yayılım mevcuttur \\
\hline $\begin{array}{l}\text { Antonakakis vd. } \\
\text { (2016) }\end{array}$ & $1977-2014$ & 28 AB ülkesi & $\begin{array}{l}\text { Endüstriyel üre- } \\
\text { tim endeksi }\end{array}$ & $\begin{array}{l}\text { Diebold-Yılmaz } \\
\text { Yayılma Endeksi }\end{array}$ & $\begin{array}{l}\text { Yayılım mevcuttur } \\
\text { ve kriz dönemle- } \\
\text { rinde yükselmekte- } \\
\text { dir. }\end{array}$ \\
\hline
\end{tabular}

Veri setini oluşturan ülkelerde meydana gelen iktisadi dalgalanmaların birbirleri aralarında ve özellikle Türkiye'ye yayılıp yayılmadığı, yayılıyorsa ne derecede yayıldığı soruları, Diebold ve Yılmaz (2009) tarafından geliştirilen "Yayılma Endeksi" yaklaşımı kullanılarak incelenmektedir. Yayılma endeksi metodolojisi iktisadi literatürde büyük ilgi görmüş olup hisse senedi fiyatlarının birlikte hareket etmesi, oynaklığın yayılımı ve tahvil getirisi yayılımı gibi konuların analizinde kullanılmaktadır (bkz., Antonakakis vd., 2013; Bubák vd., 2011; McMillan ve Speight, 2010; Yılmaz, 2010; Zhou vd., 2012). Yayılım endeksi, Prof. Dr. Kamil YILMAZ tarafından hazırlanan “Finansal ve Makro İktisadi Bağlılık" bloğu4 üzerinden küresel anlamda hisse senedi piyasası oynaklığı yayılımı, döviz kuru oynaklığı yayılımı ve devlet tahvili oynaklığı konuları için belirli aralıklarla güncellenerek yayınlanmaktadır.

\footnotetext{
${ }^{4}$ http://financialconnectedness.org/
} 
Öte yandan, iktisat politikasının iki kolundan biri olan ve merkez bankalarının uygulayabildiği para politikası, uygulama süresinin daha kısa olması nedeniyle iktisatçıların ve politikacıların iktisadi durgunluğa karşı ilk tercih ettiği tedbirler olarak karşımıza çıkmaktadır. Bu bağlamda iktisadi istikrar için para politikası büyük önem arz etmektedir. Bu nedenle araştırmanın ikinci ampirik bölümünde, para politikası ve iktisadi dalgalanmalar incelenmektedir.

İktisat politikası literatürünün para politikası bölümü incelendiğinde para politikası ile ekonomik büyüme etkileşimi sıklıkla incelenmiş ancak analizde genellikle doğrusal ekonometrik yaklaşımlar tercih edilmiştir. Oysa para politikasının ekonominin genişleme ve daralma dönemlerindeki etkisinin aynı olup olmadığı, bir başka deyişle doğrusal olup olmadığı uzun süredir makro iktisatçılar tarafından tartışılmaktadır. 1930'lu yıllara dönülecek olursa; para politikasının etkilerinin asimetrik ve ekonominin daralma döneminde daha az etkili olduğu Keynes ve Pigou tarafından öne sürülmüş, 1960'lı yıllara gelindiğinde ise, para politikasının daralma dönemlerinde daha etkin sonuçlar verebileceği iddia edilmiştir (Garcia ve Schaller, 2002: 102). Keynes, "istihdam, Faiz ve Paranın Genel Teorisi" isimli kitabında, para politikası uygulamalarının efektif talep yetersizliğini önlemede etkili olmadığını öne sürerek bunun altında yatan sebebin fiyatların aşağı yönlü katı, yukarı yönlü ise esnek olduğunu öne sürmüştür. Bu mekanizma literatürde "ipi çekme (pushing on a string)" teorisi olarak adlandırılmıştır. Para politikasının asimetrik etkileri için ipi çekme teorisini Barnichon, Matthes, ve Sablik (2017) bir benzetme yardımıyla açıklamıştır: "Bir ucunda para politikası diğer ucunda ise ekonomi olan bir ip olduğunu varsayalım. Ekonomi enflasyonist bir sürece girdiğinde, ekonomiyi soğutmak amacıyla daraltıcı para politikası uygulamak, fiyat istikrarını sağlamak için ekonominin bağlı olduğu ipin para politikası tarafından çekilmesine benzemektedir ve işe yarar bir politikadır. Öte yandan yavaşlamakta olan bir ekonomiyi canlandırmak için genişletici para politikası uygulamak ise ipi itmeye benzer ve çok etkili değildir". Bu benzetme aynı zamanda konjonktür karşıtı para politikası uygulamasını tarif etmektedir. Benzer şekilde Davig ve Doh (2013) enflasyonist dönemlerde gerçekleştirilen para politikası uygulamalarının çok daha etkili olduğunu iddia etmektedir. Öte yandan uygulanan para politikalarının daralma dönemlerinde daha etkin olduğunu savunan iktisatçılar, esnek olmayan nominal ücret ve fiyatların varlığının toplam arz eğrisini dışbükey hale getirmesiyle para politikası uygulamalarının genişleme döneminde daha etkisiz hale geldiğini iddia etmektedirler (Lenz, 1997: 441). Yakın zamanlarda yapılmış olan pek çok çalışma, para politikalarının etkilerinin ülkelere ve uygulandığı döneme özgü sonuçlar doğurduğunu, doğrusal olmadığını, bir başka deyişle de asimetrik olduğunu göstermektedir (Ergeç, 2009b; Sola vd., 2007; Tenreyro ve Thwaites, 2016; Thoma, 1994). Para politikası uygulamalarının makro iktisadi değişkenler üzerinde meydana getirdiği etkinin büyüklügü̈, uygulanan politikanın yönüne, şiddetine ve mevcut iktisadi konjonktürün durumuna göre çeşitlilik göstermesi, literatürde para politikası asimetrisi olarak ifade edilmektedir (Ergeç, 2009a: 67).

Üç asimetri çeşidi mevcuttur (Lo ve Piger, 2005: 3). Bunlar uygulanan politikanın yönünden (yön asimetrisi) ve büyüklüğünden kaynaklanan asimetriyle (büyüklük asimetrisi) birlikte mevcut ekonomik konjonktürden kaynaklanan asimetrilerdir (durum asimetrisi).

Agénor (2001)'e göre para politikasının asimetrik etkilerinin ortaya çıkışını açıklayan beş teori bulunmaktadır. Bunlar: nominal ücret yapışkanlıkları, menü maliyetleri ve asimetrik fiyat katılıkları, iktisadi kapasite, beklentiler ve son olarak kredi kullanımına dair kısıtlamalardır. Karras (1996b)'e göre bu teoriler para politikası asimetrisini arz yönlü olarak açıklamaktadırlar ve para politikası asimetrisinin talep yönü ipi çekme görüşü ile ifade edilmektedir. Para politikası asimetrisi literatüründe yapılmış olan çalışmalar Tablo 2'de özetlenmiştir: 
Aralık 2020, C. 15, S. 3

Tablo 2: Para Politikası Asimetrisi Yazın Taraması

\begin{tabular}{|c|c|c|c|c|c|}
\hline Yazar & Dönem & Ülke/Bölge & Değişkenler & Yöntem & Sonuçlar \\
\hline Cover (1992) & 1951-1987 & $A B D$ & $\begin{array}{l}\text { Parasal büyüme } \\
\text { oranı, faiz ve GSMH }\end{array}$ & İki aşamalı EKK & $\begin{array}{l}\text { Yön asimetrisi } \\
\text { mevcut }\end{array}$ \\
\hline $\begin{array}{l}\text { Morgan } \\
(1993)\end{array}$ & 1963-1992 & $A B D$ & $\begin{array}{l}\text { Politika faizi, sözel } \\
\text { göstergeler ve çıktı }\end{array}$ & İki aşamalı EKK & $\begin{array}{l}\text { Yön asimetrisi } \\
\text { mevcut }\end{array}$ \\
\hline Thoma (1994) & 1960-1989 & $A B D$ & $\begin{array}{l}\text { M1 ve endüstriyel } \\
\text { üretim endeksi }\end{array}$ & $\begin{array}{l}\text { Doğrusal olma- } \\
\text { yan VAR modeli }\end{array}$ & $\begin{array}{l}\text { Yön asimetrisi } \\
\text { mevcut }\end{array}$ \\
\hline $\begin{array}{l}\text { Rhee ve Rich } \\
\text { (1995) }\end{array}$ & $1961-1990$ & $A B D$ & $M_{2}$, faiz ve büyüme & $\begin{array}{l}\text { İki aşamalı EKK } \\
\text { ve } \mathrm{MRDM}^{5}\end{array}$ & $\begin{array}{l}\text { Yön asimetrisi } \\
\text { mevcut }\end{array}$ \\
\hline Karras (1996a) & $1953-1990$ & $\begin{array}{l}18 \text { Avrupa ül- } \\
\text { kesi }\end{array}$ & $\begin{array}{l}\text { M1 büyüme oranı, faiz } \\
\text { ve GSYiH }\end{array}$ & İki aşamalı EKK & $\begin{array}{l}\text { Yön asimetrisi } \\
\text { mevcut }\end{array}$ \\
\hline $\begin{array}{l}\text { Karras } \\
\text { (1996b) }\end{array}$ & $1950-1990$ & 38 ülke & $\begin{array}{l}\mathrm{M}_{1} \text { büyüme oranı, faiz } \\
\text { ve GSYiH }\end{array}$ & İki aşamalı EKK & $\begin{array}{l}\text { Yön asimetrisi } \\
\text { mevcut }\end{array}$ \\
\hline $\begin{array}{l}\text { Malone } \\
(2000)\end{array}$ & 1962-1999 & $A B D$ & $\begin{array}{l}\mathrm{M}_{2} \text { para arzı büyü- } \\
\text { mesi ve endüstriyel } \\
\text { çıktı }\end{array}$ & İki aşamalı EKK & $\begin{array}{l}\text { Yön asimetrisi } \\
\text { mevcut değil }\end{array}$ \\
\hline Agénor (2001) & 1978-1999 & $\begin{array}{l}\text { Kore, Ma- } \\
\text { lezya, Filipin- } \\
\text { ler ve Türkiye }\end{array}$ & $\begin{array}{l}\text { Piyasa faiz oranı, re- } \\
\text { eskont oranı, parasal } \\
\text { taban ve çıktı }\end{array}$ & VAR modeli & $\begin{array}{l}\text { Asimetrik etki } \\
\text { mevcut }\end{array}$ \\
\hline $\begin{array}{l}\text { Dolado ve } \\
\text { María Dolores } \\
\text { (2001) }\end{array}$ & 1977-1997 & İspanya & $\begin{array}{l}\text { Politika faizi ve reel } \\
\text { GSYiH büyümesi }\end{array}$ & MRDM & $\begin{array}{l}\text { Durum asimet- } \\
\text { risi mevcut }\end{array}$ \\
\hline $\begin{array}{l}\text { Garcia ve } \\
\text { Schaller } \\
(2002)\end{array}$ & 1947-1993 & $A B D$ & $\begin{array}{l}\text { Tüketici fiyatları, } \mathrm{M}_{1} \text {, } \\
\text { politika faizi ve bü- } \\
\text { yüme }\end{array}$ & MRDM & $\begin{array}{l}\text { Durum asimet- } \\
\text { risi mevcut }\end{array}$ \\
\hline Ergeç (2009b) & $1990-2006$ & Türkiye & $\begin{array}{l}\mathrm{M}_{2} \text { büyümesi, faiz } \\
\text { oranları, sanayi üre- } \\
\text { tim endeksi, TÜFE ve } \\
\text { döviz kuru }\end{array}$ & İki aşamalı EKK & $\begin{array}{l}\text { Yön asimetrisi } \\
\text { mevcut }\end{array}$ \\
\hline $\begin{array}{l}\text { Kandemir } \\
\text { Kocaaslan } \\
(2013)\end{array}$ & $1981-2009$ & $A B D$ & $\begin{array}{l}\text { Politika faizi, endüst- } \\
\text { riyel üretim endeksi } \\
\text { ve finansal derinlik }\end{array}$ & MRDM & $\begin{array}{l}\text { Durum asimet- } \\
\text { risi mevcut }\end{array}$ \\
\hline Biçici (2015) & $1998-2014$ & $\begin{array}{l}11 \text { adet Orta } \\
\text { Asya ve Bal- } \\
\text { kan ülkesi }\end{array}$ & $\begin{array}{l}\mathrm{M}_{2} \text {, TÜFE ve sanayi } \\
\text { üretim endeksi }\end{array}$ & İki aşamalı EKK & $\begin{array}{l}\text { Yön asimetrisi } \\
\text { mevcut }\end{array}$ \\
\hline $\begin{array}{l}\text { Ülke ve } \\
\text { Berument } \\
(2015)\end{array}$ & $1990-2014$ & Türkiye & $\begin{array}{l}\text { Bankalararası gecelik } \\
\text { faiz oranı, endüstriyel } \\
\text { çıktı büyümesi, döviz } \\
\text { kuru ve TüFE }\end{array}$ & $\begin{array}{l}\text { Doğrusal olma- } \\
\text { yan otoregresif } \\
\text { model }\end{array}$ & $\begin{array}{l}\text { Yön asimetrisi } \\
\text { mevcut }\end{array}$ \\
\hline $\begin{array}{l}\text { Yılancı vd. } \\
(2016)\end{array}$ & $1990-2013$ & Türkiye & $\begin{array}{l}\text { Faiz, çıktı, sermaye pi- } \\
\text { yasası, döviz kuru ve } \\
\text { TÜFE }\end{array}$ & $\begin{array}{l}\text { Asimetrik etki } \\
\text { tepki fonksi- } \\
\text { yonu }\end{array}$ & $\begin{array}{l}\text { Yön asimetrisi } \\
\text { mevcut }\end{array}$ \\
\hline
\end{tabular}

${ }^{5}$ Markov Rejim Değişimi Modeli 
Bu çalışmanın öncelikli amacı uygulanan para politikasının ekonominin genişleme ve daralma fazlarına girip çıktığı dönemlerde reel çıktı üzerinde asimetrik bir etkiye sahip olup olmadığını araştırarak "para politikasının konjonktürel etkisini” ortaya koymaktır. Bu amaçla doğrusal olmayan bir tahmin yöntemi olan Markov Rejim Değişimi Modeli kullanılarak "Uygulanan para politikalarının toplam çıktı üzerindeki etkileri farklı konjonktürel evrelerde gerek yönü gerek de gücü açısından farklı mıdır?" sorusuna cevap aramaktır. Markov Rejim Değişimi Modeli, doğrusal tahmin yöntemlerinin aksine, doğrusal olmayan ve asimetrik seriler üzerinde çalışmak için daha uygundur (Garcia ve Schaller, 2002: 103).

Markov Rejim Değişimi yaklaşımı kullanılarak elde edilen bulgular, çalışmanın birinci ampirik bölümünden elde edilecek olan sonuçlarla birleştirilecek ve söz konusu ülkelerden Türkiye'ye yayılabilecek iktisadi dalgalanmalar göz önünde bulundurularak Türkiye'nin içine girebileceği olası makroekonomik koşullar dikkate alınarak konjonktürel para politikası önerisinde bulunulacaktır. Maliye politikası gibi para politikasının da ekonomi üzerindeki etkileri gecikmeli olarak ortaya çıkabilmektedir (Friedman, 1961: 447). Ancak bu gecikme, genellikle maliye politikasında olduğu gibi bürokratik süreçlerin uzun olması veya politik kararların çatışması gibi sebeplerden ziyade, teşhis gecikmesi ve uygulama gecikmesi olarak adlandırılan zincirleme süreçten kaynaklanmaktadır. Bu noktada, ülkenin iktisadi durumunun takip eden dönemlerde ne şekilde olacağının tahmin edilmesi ve hatta mevcut durumunun ne olduğunun iyi bir şekilde anlaşılabilmesi, teşhis ve uygulama gecikmelerinin önüne geçilebilmesi ve etkin politika geliştirilebilmesi açısından büyük önem kazanmaktadır. Bu bağlamda, iktisadi dalgalanmaların uluslararası yayılımının anlaşılması, ülkenin iktisadi durumunun gelecek dönemlerde ne şekilde olabileceğinin tahmin edilmesi ve mevcut durumunun daha iyi anlaşılabilmesi, koşullara uygun iktisadi politikaların geliştirilebilmesi açısından faydalı olabilecektir.

\section{Veri ve Yöntem}

\subsection{Veri}

Literatürde para politikası göstergesi olarak genellikle M1, M2 ve M3 gibi parasal büyüklüklerle birlikte çeşitli faiz oranları kullanılmaktadır. Ancak parasal büyüklüklerin para politikası göstergesi olarak kullanılması birtakım sorunları da beraberinde getirmektedir. Bu sorunlardan ilki, para politikasında meydana gelen her değişikliğin, parasal büyüklüklere yansıyamayabileceği gerçeğidir. Bununla birlikte, çeşitli parasal büyüklük ölçüleri farklı yönlerde değişerek parasal duruş hakkında birbirleri ile çelişen görünümler sergileyebilmektedirler. Sonuç olarak, ekonometrik modele parasal göstergelerin eklenmesi, para politikası şoklarının eksik ya da hatalı yorumlanmasına neden olabilmektedir (Florio, 2004: 414-415; Garcia ve Schaller, 2002: 111; Morgan, 1993: 21). Tüm bu etkenler göz önüne alındığında, politika faizlerinin parasal büyüklüklerden daha istikrarlı göstergeler olduğu iddia edilmektedir (Garcia ve Schaller, 2002: 103; Ravn ve Sola, 2004: 42). Ayrıca, merkez bankaları ekonomiye politika faizi vasıtasıyla hızlı bir şekilde müdahale ettikleri için, politika faizi parasal duruşu daha iyi temsil etmektedir (Garcia ve Schaller, 2002: 103). Merkez bankası müdahalelerinin büyük bir kısmı, piyasa faiz oranlarını etkileyen politika faizi değişiklikleriyle gerçekleştirilmektedir (Ravn ve Sola, 2004: 52). Bu ve benzeri nedenlerle, politika faiz oranlarının para politikası göstergesi olarak kullanımı literatürde oldukça yaygındır (Höppner vd., 2008: 2356; Lenz, 1997: 443). Para politikası göstergesi olarak faiz oranının kullanılmasının bir başka avantajı, parasal büyüklüklere göre daha hızlı ve daha basit bir şekilde ölçülmesidir (Mishkin, 2005: 91). Bu nedenlerle bu çalışmada, para politikası göstergesi olarak OECD veri tabanından elde edilmiş olan bankalar arası gecelik faiz oranı kullanılmıştır. Para politikasının ekonomik konjonktür üzerindeki asimetrik etkilerinin ölçülmesi 
amacıyla ise, reel GSYiH büyümesi değerlerinden faydalanılmıştır. Büyüme verileri, St. Louis Federal Rezerv Bankası veri tabanından temin edilmiştir. Konjonktür karşıtı iktisat politikaları hakkında yapılan çalışmalar, dış ticaret ilişkilerine ve ekonomik bağımlılığa sıklıkla atıfta bulunmaktadır. Bu nedenle reel döviz kuru ekonometrik modele kontrol değişkeni olarak eklenmiştir. Döviz kuru değerleri usd/try paritesini göstermektedir ve OECD veri tabanından alınmışlardır. Modelde kullanılan değişkenler logaritmaları alınarak kullanılmıştır ve Türkiye ekonomisinin 1998:Ç2-2018:Ç3 dönemini temsil etmektedir. Modelin tahmini için STATA 14 programı kullanılmıştır.

Yayılma endeksi metodolojisi için, OECD veri tabanından alınmış olan aylık endüstriyel üretim endeksi tercih edilmiştir. Yayılım endeksi için endüstriyel üretim endeksinin tercih edilmesinin en önemli sebebi, milli gelir muhasebesi hesaplarının aylık yayınlanmıyor olmasıdır. Yayılım endeksi metodolojisi, aylık veriler ile daha iyi performans göstermektedir. Çünkü aylık veriler ile uluslararası iktisadi dalgalanmalar arasındaki karşılıklı bağımlılık daha kolay yakalanabilmektedir ve aylık frekansa sahip veriler yayılma endeksinin hesaplanmasında daha fazla gözlem kullanılmasına yardımcı olmaktadır (Diebold ve Yılmaz, 2013: 2). Çalışmada gerçekleştirilen ampirik analizde, Türkiye ve pek çok sanayileşmiş ekonomiyi de içeren 24 ülkelik ${ }^{6}$ bir veri setinden faydalanılmıştır. Veri seti 1985 Ocak-2018 Kasım dönemini kapsamaktadır. Bu çalışmanın da en büyük kısıtlarından birisi veri yetersizliğidir ve analiz, elde edilebilen en geniş veri seti ${ }^{7}$ ile gerçekleştirilmiştir. Diebold ve Yılmaz yayılma endeksi bulguları WinRATS Pro 8.0 programı ile elde edilmiş olup uygulama için gerekli olan kodlar "http://financialconnectedness.org" internet adresi vasıtasıyla elde edilmiştir.

\subsection{Yöntem}

\subsubsection{Diebold ve Yılmaz Yayılma Endeksi Metodolojisi}

Diebold ve Yılmaz (2009) "Yayılma Endeksi” metodolojisi, N değişkenli vektör hata düzeltme modelinden türetilmiş olan varyans ayrıştırması ve VAR modellerine dayanmaktadır. Bu yakla-

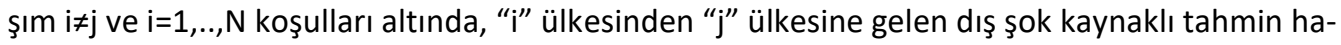
tası varyansı paylarının, her bir "i" ülkesi için ayrıştırılmasını ifade etmektedir. Ayrıştırma işlemi Cholesky faktörizasyonu kullanılarak gerçekleştirilmektedir.

Modeli basitleştirerek açıklayabilmek amacıyla ilk olarak kovaryans durağan, birinci derece ve iki değişkenli basit bir VAR modelini ele alalım,

$$
\mathrm{x}_{\mathrm{t}}=\theta_{\mathrm{i}} \mathrm{x}_{\mathrm{t}-\mathrm{i}}+\varepsilon_{\mathrm{t}}
$$

Denklem 2.1'de yer alan, $x_{t}=\left(x_{1 t}, x_{2 t}\right)$ ifadesi 2 adet içsel değişkene ait vektörler, $\theta$ ifadesi $2 \times 2$ parametre matrisi, $\varepsilon_{\mathrm{t}} \sim\left(0, \sigma^{2}\right)$ dağılıma sahip olan hata terimleri matrisi ve $t=1,2, \ldots, T$ zaman endeksidir. VAR modelinin hareketli ortalamalar gösterimi yapılabilmektedir ve Denklem $2.2^{\prime}$ de gösterilmektedir:

$$
\mathrm{x}_{\mathrm{t}}=\varphi(\mathrm{L}) \varepsilon_{\mathrm{t}}, \quad \varphi(\mathrm{L})=(\mathrm{I}-\theta \mathrm{L})^{-1} \text { olmak üzere }
$$

hareketli ortalamalar gösterimi farklı bir şekilde yeniden yazılacak olursa

$$
\mathrm{A}(\mathrm{L})=\varphi(\mathrm{L}) \mathrm{Q}_{\mathrm{t}}^{-1}, \quad \mathrm{u}_{\mathrm{t}}=\mathrm{Q}_{\mathrm{t}} \varepsilon_{\mathrm{t}} \text { ve I }=\mathrm{E}\left(\mathrm{u}_{\mathrm{t}} \mathrm{u}_{\mathrm{t}}^{\prime}\right) \text { olmak üzere } \mathrm{x}_{\mathrm{t}}=\mathrm{A}(\mathrm{L}) \mathrm{u}_{\mathrm{t}} \text { elde edilir (2.3) }
$$

\footnotetext{
${ }^{6} \mathrm{ABD}$, Almanya, Avusturya, Belçika, Brezilya, Danimarka, Fransa, Hollanda, İngiltere, İrlanda, İspanya, İsrail, İsveç, İtalya, Kanada, Kore, Lüksemburg, Macaristan, Meksika, Norveç, Japonya, Portekiz, Türkiye, Yunanistan.

${ }^{7}$ Eksik veri içeren ülkeler analiz dışı bırakılmıştır.
} 
Denklem 2.3'te yer alan $\mathrm{Q}_{\mathrm{t}}^{-1}$ ifadesi $\varepsilon_{\mathrm{t}}{ }^{\prime}$ nin kovaryans matrisininin alt üçgen Cholesky faktörünü göstermektedir. Bir dönem sonrasının tahminlendiği model göz önüne alınacak olursa, optimal tahminleme şu şekilde olacaktır:

$$
\mathrm{x}_{\mathrm{t}+1, \mathrm{t}}=\theta \mathrm{x}_{\mathrm{t}}
$$

Bir dönem sonrasının tahminlendiği modele ait hata vektörü ise aşağıdaki gibidir:

$$
e_{t+1, t}=x_{t+1}-x_{t+1, t}=A_{0} u_{t+1}=\left[\begin{array}{ll}
a_{0,11} & a_{0,12} \\
a_{0,21} & a_{0,22}
\end{array}\right]\left[\begin{array}{l}
u_{1, t+1} \\
u_{2, t+1}
\end{array}\right]
$$

Denklem 2.5'e ait olan kovaryans matrisi:

$$
E\left(e_{t+1}, e_{t+1, t}^{\prime}\right)=A_{0} A_{0}^{\prime} \quad \text { şeklinde elde edilir. }
$$

Buradan, $\mathrm{x}_{1 \mathrm{t}}$ 'nin tahminindeki bir dönem sonrası hata teriminin varyansı $a_{0,11}^{2}+a_{0,12}^{2}$ şeklinde $\mathrm{x}_{2 \mathrm{t}}{ }^{\prime}$ nin tahminindeki bir dönem sonrası hata teriminin varyansı ise $a_{0,21}^{2}+a_{0,22}^{2}$ şeklinde elde edilmektedir. Varyans ayrıştırması yöntemi sayesinde her bir değişkene ait tahmin hatası varyansları, her bir ülke için ayrı ayrı elde edilebilmektedir. Bu sayede $\mathrm{x}_{1}$ ülkesinin tahminindeki bir dönem sonrası hata terimi varyansının ne kadarının $\mathrm{x}_{1}$ ülkesinin kendi iç şoklarından, ne kadarının $\mathrm{x}_{2}$ ülkesinden $\mathrm{x}_{1}$ ülkesine yayılan şoklardan kaynaklandığı ayrı ayrı elde edilebilecektir. $\mathrm{x}_{\mathrm{i}}$ ülkesinin tahminindeki bir dönem sonrası hata terimi varyansının, $\mathrm{x}_{\mathrm{i}}$ $(i=1,2)$ ülkesinin kendi iç şoklarından kaynaklanan bölümü "kendi varyans payı" olarak tanımlanmaktadır ve ülkelerin kendilerine özgü şoklarını ifade etmektedir. $\mathrm{x}_{\mathrm{i}}$ ülkesinin tahminindeki bir dönem sonrası hata terimi varyansının, $x_{j}(i, j=1,2$ ve $i \neq j)$ ülkesinin şoklarından kaynaklanan bölümü "çapraz varyans payı" olarak tanımlanmıştır ve iktisadi dalgalanmaların yayılımını ifade etmektedir. Buraya kadar olan bölümde açıklanmış olan iki değişkenli basit örnekte, iki tip yayılma gerçekleşebilmektedir: $x_{1 \mathrm{t}}$ ülkesine özgü olan şoklar $x_{2 \mathrm{t}}$ ülkesinin tahmin hatası varyansını $a_{0,21}^{2}\left(\mathrm{x}_{1 \mathrm{t}}\right.$ ülkesindenden $\mathrm{x}_{2 \mathrm{t}}$ ülkesi yönlü yayılma) kadar etkilemekte ve $\mathrm{x}_{2 \mathrm{t}}$ ülkesine özgü olan şoklar $\mathrm{x}_{1 \mathrm{t}}$ ülkesinin tahmin hatası varyansını $a_{0,12}^{2}$ ( $\mathrm{x}_{2 \mathrm{t}}$ ülkesindenden $\mathrm{x}_{1 \mathrm{t}}$ ülkesi yönlü yayılma) kadar etkilemektedir. Buradan, toplam yayılma " $a_{0,12}^{2}+a_{0,21}^{2}$ şeklinde elde edilebilmektedir.

$$
a_{0,11}^{2}+a_{0,12}^{2}+a_{0,21}^{2}+a_{0,12}^{2}=\mathrm{iz}\left(\mathrm{A}_{0} \mathrm{~A}_{0}\right)
$$

$\mathrm{Bu}$ ifadenin yüzdesel olarak gösterimi olan yayılma endeksi ise aşağıdaki gibi formülize edilmektedir:

$$
S=\frac{a_{0,12}^{2} a_{0,21}^{2}}{i z\left(A_{0} A_{0}^{\prime}\right)} x 100
$$

Denklem 2.8 yayılma endeksinin birinci derece iki değişkenli VAR modeli ile oluşturulmuş bir dönem sonrası tahminini kullanan basit bir şeklini göstermektedir. Yayılma endeksinin H dönem sonrası tahmini kullanan $\mathrm{p}$. derece $\mathrm{N}$ değişkenli VAR modeline genişletilmiş genel hali aşağıdaki gibidir:

$$
S=\frac{\sum_{h=0}^{H-1} \sum_{i, j=1}^{N} a_{h, i j}^{2}}{\sum_{h=0}^{H-1} i z\left(A_{0} A_{0}^{\prime}\right)} x 100
$$

\subsubsection{Markov Rejim Değişim Modeli}

ABD Ulusal Ekonomik Araştırmalar Bürosu (NBER) İş Çevrimleri Değerlendirme Komitesi, $A B D$ ekonomisine ait iktisadi dalgalanmaların kronolojik yapısını incelemektedir. Bu bağlamda ABD’nin ekonomik faaliyetinin izlediği dip ve zirve noktaları kayıt altına alınarak, konjonktürel analizlerin yapılmasına olanak sağlanmaktadır. James D. Hamilton, 1953-1984 dönemindeki çeyreklik ekonomik büyüme oranlarını kullanarak, ABD ekonomisinin iktisadi dalgalanmalarını 
geliştirdiği yöntem ile tespit etmeye çalışmıştır. Yöntem sonucu elde edilen iktisadi dönüm noktaları, ABD Ulusal Ekonomik Araştırmalar Bürosu İş Çevrimleri Değerlendirme Komitesi tarafından ilan edilen tarihler ile tutarlı bulunmuştur. Bir başka deyişle, Hamilton (1989) modeli, iktisadi dalgalanmaların dönüm noktalarını başarı ile tahminleyerek, ele alınan dönemi genişleme ve daralma rejimlerine ayırabilmektedir. Inceleme sonucunda sadece bir rejim bulunması durumunda ise, model standart doğrusal bir tahminleme yöntemine indirgenmektedir (Kakes, 1998: 5). Öte yandan, Türkiye ekonomisi için ABD'deki İş Çevrimleri Değerlendirme Komitesi benzeri bir kuruluş mevcut değildir ve bu konuda resmî açıklamalar yapılmamaktadır (Ülke ve Berument, 2015: 7). Markov rejim değişikliği yöntemi, iktisadi rejimleri tahminlemedeki başarısıyla bu eksikliği giderebilmektedir.

Bu çalışmada Markov rejim değişim modellerinin bir çeşidi olan Markov rejim değişimi otoregresif modeli "MS-AR" kullanılmıştır. MS-AR modeli genel olarak MS(m)-AR(p) olarak ifade edilmektedir. Bu ifadedeki " $m$ " parametresi incelenen serideki rejim sayısını, $p$ değeri ise modeldeki bağımsız değişkenin gecikmeli değerlerinden oluşan otoregresif kısımı göstermektedir. $\mathrm{MS}(\mathrm{m})-\mathrm{AR}(\mathrm{p})$ modeli genel olarak aşağıdaki gibi gösterilmektedir:

$$
X_{t}=s_{t} \mu_{1}+\left(1-s_{t}\right) \mu_{2}+\varepsilon_{t}
$$

Denklem 2.10' da yer alan " $\varepsilon_{\mathrm{t}}$ " ifadesi ortalaması 0 ve varyansı $\sigma^{2}\left(\varepsilon_{\mathrm{t}} \sim \mathrm{N}\left(0, \sigma^{2}\right)\right.$ olan hata terimidir. "st" parametresi ise, gözlemlenemeyen durum değişkenidir ve bu çalışma kapsamında ekonominin daralma ile genişleme rejimleri için 0 ya da 1 değerini almaktadır. Durum değişkeni 1 değerini aldığı zaman model,

$$
X_{t}=\mu_{1}+\varepsilon_{t}
$$

durum değişkeninin 0 değeri için ise,

$$
X_{t}=\mu_{2}+\varepsilon_{t}
$$

şeklinde elde edilmektedir. Sistemde iki veya ikiden fazla rejim olması durumunda, durum değişkeni $k$ farklı değer alabilecek ve model aşağıdaki hale gelecektir.

$$
X_{t}=\mu_{s_{t}}+\varepsilon_{t} \quad, \quad \mathrm{~s}_{\mathrm{t}}=1,2, \ldots, \mathrm{k}
$$

Tek veya çok değişkenli Markov rejim değişimi modeli, modele bağımsız değişkenin $p$ adet gecikmeli değerlerinin eklenmesiyle MS-AR(p) modeli olarak genişletilebilmektedir:

$$
X_{t}=c\left(s_{t}\right)+\beta_{1}\left(s_{t}\right) X_{t-1}+\cdots+\beta_{p}\left(s_{t}\right) X_{t-p}+\left(s_{t}\right) u_{t}
$$

$\operatorname{MS}-A R(p)$ modelleri yardımıyla, iktisadi konjonktürün hangi döneminde olunduğu, bu rejimin devam etme olasılığı veya bu rejimden bir diğer rejime geçmenin olasılı̆̆ belirlenebilmektedir. Bu olasılıklar rejim geçiş olasılığı olarak adlandırılmıştır ve aşağıdaki matris ile gösterilmektedirler:

$$
p_{i j}=\left(\begin{array}{ll}
p_{11} & p_{12} \\
p_{21} & p_{22}
\end{array}\right)
$$

Rejim geçiş matrisindeki her bir değer,

$$
P\left(\frac{s_{t=j}}{s_{t-1=\mathrm{i}}}\right)=p_{\mathrm{i} j} \quad \mathrm{j}=1,2
$$

şeklindeki koşullu olasılık fonksiyonu şeklinde gösterilebilmektedir. Bu fonksiyondaki "i” indisi, içerisinde bulunulan rejimi, "j" indisi ise içerisine girilecek olan rejimi göstermektedir. Örneğin $\mathrm{P}_{12}$ koşullu olasılık değeri, sürecin birinci rejimden ikinci rejime geçme olasılığını göstermektedir. 


\section{Ampirik Bulgular ve Sonuç}

\subsection{Diebold ve Yılmaz Yayılma Endeksi Bulguları}

Var modeline dayanan Yayılma endeksi metodolojisi için optimal gecikme uzunluğu Akaike bilgi kriteri yardımıyla 2 olarak belirlenmiştir. Elde edilen bulgular, yayılma tablosu olarak adlandırılan Tablo 3'te sunulmaktadır. Matris formunda incelenebilecek olan yayılma tablosunun satırları dışarıdan gelen şokları (tahmin-hata varyansı), sütunları ise dışarıya giden iktisadi şokları ölçmektedir. Buna göre " $\mathrm{i}$ ” ülkesine " $\mathrm{j}$ " ülkesinden gelen iktisadi şok, yayılım tablosunda "i" ülkesinin yer aldığı satır ile "j" ülkesinin yer aldığı sütunun kesiştiği noktada gözlemlenebilmektedir. Yayılma tablosunun en sağ sütununda yer alan değerler, satırlardaki ülkelere diğer ülkelerden gelen dış şokların toplam yüzdesini göstermektedir ve yayılma endeksi değerleridir. Yayılma endeksi değerleri, "i" ülkesinin yer aldığı satırdaki değerler ile oluşturulan bir oran ile hesaplanmaktadır. Bu oranın payı, yayılım tablosu matrisinin köşegen değeri hariç tutularak "i" ülkesinin yer aldığı satırdaki değerlerin toplanması ile elde edilmektedir. Oranın paydası ise, "i" ülkesinin yer aldığı satırdaki değerlerin tamamının toplamı ile bulunmaktadır. Bu değerler tabloda "diğerlerinden" olarak adlandırılmıştır.

Yayılım tablosunun sol alt köşesinde yer alan "diğerlerine" satırı ise, "i" ülkesinden diğer ülkelere yayılan iktisadi dalgalanmaların tahmin-hata varyansı cinsinden ölçüsüdür. Diğerlerine değeri, "i" ülkesinin kendi iç şokları hariç tutularak hesaplanmaktadır. Analizde yer alan ülkelerin kendi iç şokları ile yabancı piyasalara yayılan şokların toplamı ise "diğerlerine*" satırında gösterilmektedir.

Yayılma tablosundan elde edilen bulgular, uluslararası iktisadi dalgalanmaların yayılımının en önemli kaynaklarının ABD, İngiltere, Almanya, Japonya, Güney Kore ve İspanya gibi sanayileşmiş ekonomiler olduğu göstermektedir. Bu bulgular lokomotif hipotezini ${ }^{8}$ desteklemektedir (lokomotif hipotezi hakkında ayrıntılı bilgi için, bkz. İbrahim, 2003: 12). Yayılım endeksi bulgularına göre, Türkiye ekonomisini etkileyen iktisadi şokların (tahmin-hata varyansının) \%48'i iktisadi dalgalanmaların uluslararası yayılımından kaynaklanmaktadır. Geriye kalan \%52'lik kısım ise Türkiye'nin kendi iç şoklarını temsil etmektedir. Yayılım tablosunda Türkiye'nin yer aldığı satır incelendiğinde, Türkiye'de meydana gelen iktisadi dalgalanmaların \%12,5'inin Güney Kore'den, \%8,4'ünün ABD’nden, \%6,4'ünün Japonya'dan, \%4,5'inin sınır komşumuz Yunanistan'dan ve \%3,2'sinin ise İspanya ekonomisinden gelen dış şoklardan kaynaklandığı görülmektedir.

\footnotetext{
${ }^{8}$ Lokomotif hipotezine göre sanayileşmiş ülkeler dünya ekonomisinin lokomotifi niteliğindedirler. ABD, Japonya gibi büyük ekonomiler ya da $A B$ gibi gelişmiş topluluklar, bir lokomotif gibi hareket ederek küresel ekonomiye yön vermekte ve kendilerine özgü şokları az gelişmiş ve gelişmekte olan piyasa ekonomilerine aktarmaktadırlar.
} 


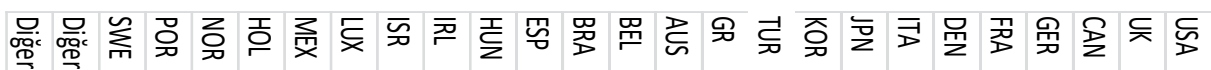
产.

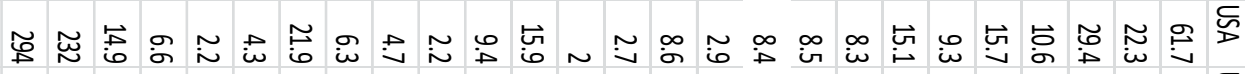

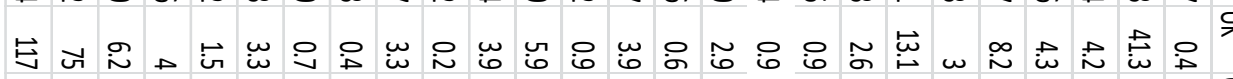

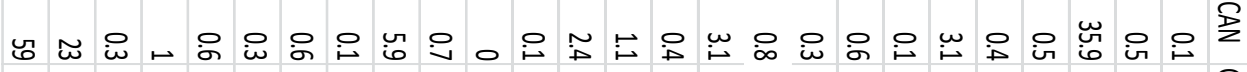
๑凹

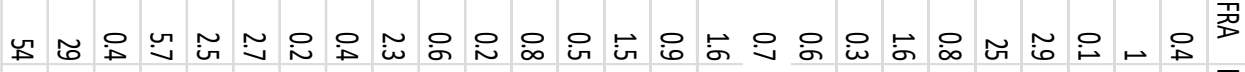

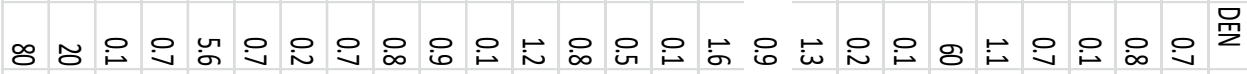
n m n

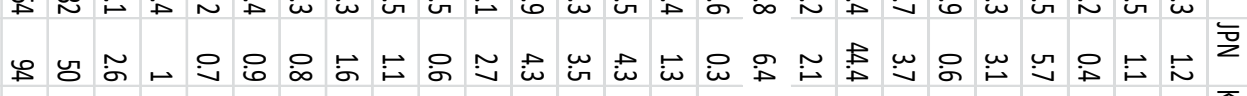

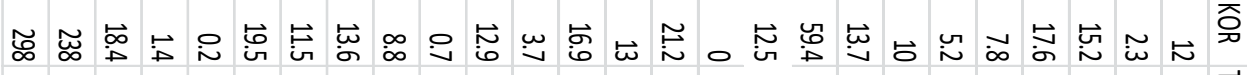

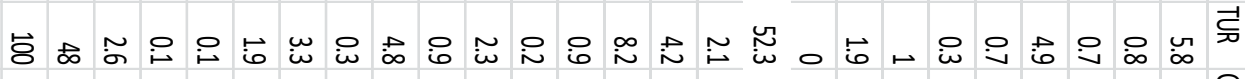

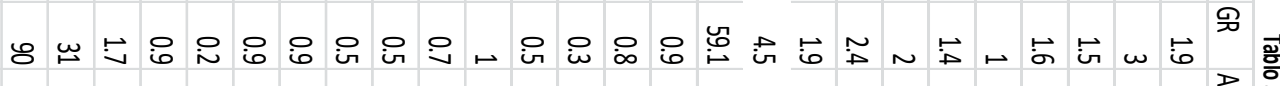

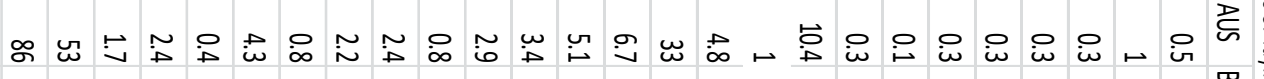
M

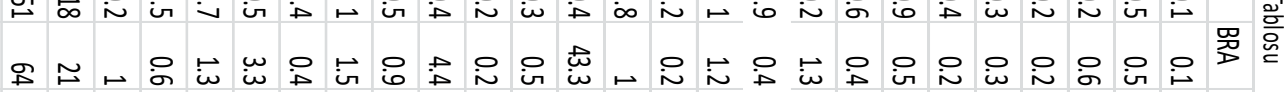

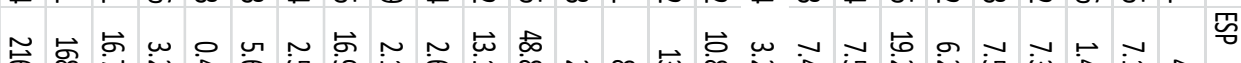

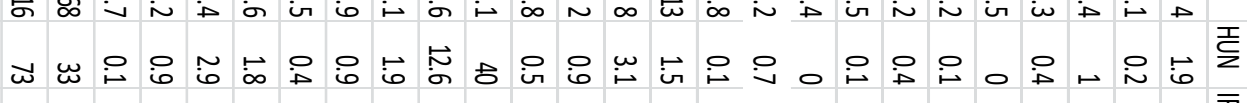

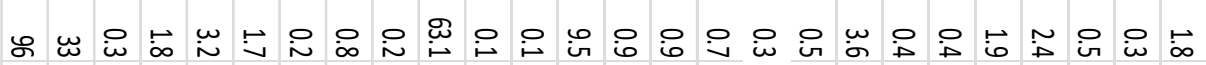

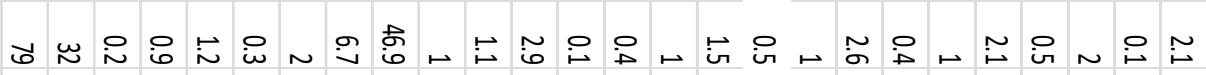

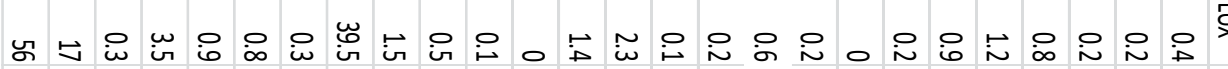

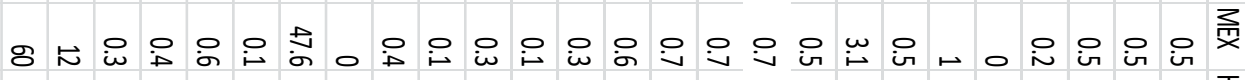

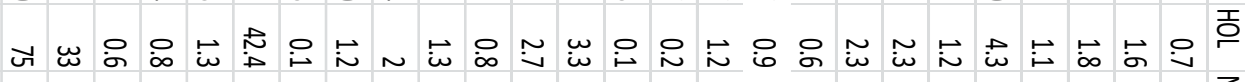

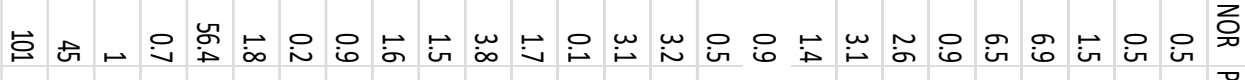

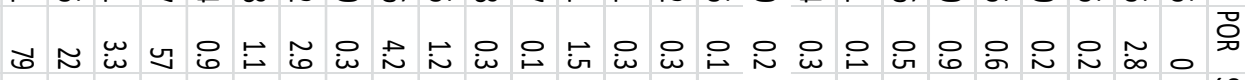

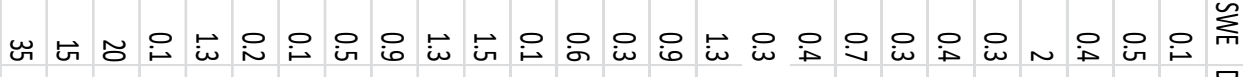

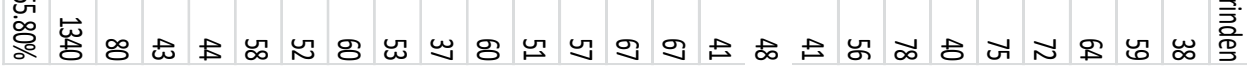


Bu sonuçlar, lokomotif hipotezinde iddia edildiği üzere, sanayileşmiş ülkelerde meydana gelen iktisadi şokların gelişen bir piyasa ekonomisi olan Türkiye üzerinde önemli etki yarattığını göstermektedir. Bu bağlamda, bu ülkelerin iktisadi koşullarının, Türkiye ekonomisi için bir öncü gösterge niteliğinde olabileceği iddia edilebilir.

Yayılım tablosundan çıkarılabilecek bir başka önemli bulgu ise, ülkeler arası çeşitli yayılım endeksi değerlerini tek bir değere indirgeyerek özetleyen ve yayılım tablosunun sağ alt köşesinde yer alan "Toplam Yayılma Endeksi" değeridir. Toplam yayılma endeksi, dış şokları temsil eden "diğerlerine" sütunu toplamının, ülkelerin kendi iç şokları ile yabancı piyasalara yayılan şokların toplamını gösteren "diğerlerine*" satırı toplamına bölünmesi ile elde edilmektedir. Toplam yayılma endeksi, dış şokların toplam iktisadi şoklar içerisindeki payını vermektedir. Bu çalışma neticesinde elde edilen toplam yayılma endeksine göre, 1985 Ocak-2018 Kasım dönemi süresince meydana gelen tahmin-hata varyanslarının \%55,8'i uluslararası iktisadi dalgalanmaların yayılımından kaynaklanmaktadır.

\subsection{Para Politikası Şoklarının Reel Asimetrik Etkisi}

\subsubsection{Durağanlık Analizi}

Durağanlık, bir zaman serisinin ortalamasının ve varyansının zaman boyunca değişken olmaması olarak tanımlanmaktadır. Ancak iktisadi zaman serilerinin yapıları ve doğaları gereğince ortalamaları ve varyansları değişken olabilmektedir. Durağan olmayan serilerin kullanıldığı regresyon modelleri, yanıltıcı ve gerçekçi olmayan analiz bulgularının elde edilmesine yol açmaktadır ve bu durum sahte regresyon olarak ifade edilmektedir (Granger ve Newbold, 1974: 117). Bu sorundan kaçınmak amacıyla, serilerin durağanlığının test edilmesi ve durağan hale getirilmiş seriler ile modelleme yapılması gerekmektedir. Bu nedenle bu çalışma kapsamında kullanılan veriler için durağanlık sınaması ilk olarak geleneksel bir birim kök testi olan Dickey ve Fuller $(1979,1981)$ ADF testi ile yapılmıştır. Bunun yanı sıra, zaman serilerinde meydana gelen yapısal kırılmalar, yapısal kırılma tarihinden itibaren zaman boyunca değişmeme özelliğine sahip olan yeni bir ortalama ve varyans oluşturabilmektedir. Gerçekte durağan olabilen bu serilerde uygulanan geleneksel birim kök testleri, birim kökün var olduğunu ifade eden boş hipotezi kabul edebilmektedir. Bu olgu sahte birim kök olarak adlandırılmaktadır ve bu sorunu ortadan kaldırmak için yapısal kırılmalara izin veren birim kök testleriyle de sınama yapılması gerekmektedir (Barışık ve Çevik, 2008: 73; Korkmaz vd., 2008: 24; Liu ve Chen, 2018: 317). Bu amaçla bu çalışmada yapısal kırılmaları hesaba katan Zivot ve Andrews (1992) "ZA" birim kök testi de uygulanmıştır.

Tablo 4: Birim Kök Sınaması

\begin{tabular}{lllll}
\hline Değişken & ADF & & ZA & \\
\hline & Düzey & 1. Fark & Düzey & 1. Fark \\
\hline Gsyih & $-7.44^{* * *}$ & & $-10.64^{* * *}$ & \\
Faiz & -1.74 & $-8.88^{* * *}$ & -2.16 & $-8.28^{* * *}$ \\
Kur & -2.17 & $-5.56^{* * *}$ & -3.43 & $-7.71^{* * *}$ \\
\hline
\end{tabular}

$*, * *$ ve *** sırasıyla \%10, \%5 ve \%1 düzeyinde anlamlılı̆ı ifade etmektedir.

ADF ve ZA birim kök testleri GSYIH serisinin düzeyde durağan olduğuna dair bulgular vermektedir. Faiz serisi için yapılan ADF ve ZA birim kök sınamaları, serinin düzeyde durağan olmadığını, ancak serinin birinci farkının \%1 anlamlılık düzeyinde durağan olduğunu göstermektedir. Öte yandan, Kur değişkeni için yapılan birim kök sınamalarının boş hipotezi olan "Seride birim 
kök yoktur" ifadesi her iki birim kök testi tarafından \%1 anlamlılık düzeyinde reddedilmiştir. Kur serisi, birinci farkının alınmasıyla durağan hale gelmektedir.

\subsubsection{Markov Rejim Değişim Modeli Bulguları}

Doğrusal regresyon modeli para politikasının konjonktürel reel etkilerinin gözlemlenmesine olanak sağlamamaktadır. Öte yandan Markov rejim değişimi yöntemi para politikalarının büyüme üzerindeki etkilerini, ekonominin büyüme ve daralma rejimleri için ayrı ayrı gösterme özelliğine sahiptir. Para politikası asimetrisinin test edilmesi için tahminlenmiş olan ekonometrik model aşağıdaki gibidir:

$$
\begin{gathered}
\text { gsyih }_{t}=\left[\alpha_{0}\left(1-s_{t}\right)+\alpha_{1} s_{t}\right]+\left[\gamma_{0}^{(1)}\left(1-s_{t}\right)+\gamma_{1}^{(1)} s_{t}\right] g_{s y i h_{t-1}}+. .+ \\
{\left[\gamma_{0}^{(4)}\left(1-s_{t}\right)+\gamma_{1}^{(4)} s_{t}\right] g s_{i j} h_{t-4}+\left[\beta_{0}\left(1-s_{t}\right)+\beta_{1} s_{t}\right] \text { faiz }_{t-1}+} \\
{\left[\theta_{0}\left(1-s_{t}\right)+\theta_{1} s_{t}\right] k u r_{t}+\left[\sigma_{0}\left(1-s_{t}\right)+\sigma_{1} s_{t}\right] \varepsilon_{t}}
\end{gathered}
$$

Çalışmada MS(2)-AR(4) modeli kullanılmıştır. Bu ifade modelde iki rejim (daralma ve genişleme) olduğunu ve Hamilton (1989) ile uyumlu olarak modelin dördüncü derece otoregresif olduğunu ifade etmektedir. Tahminlenmiş olan GSYiH büyüme denklemi, GSYiH büyümesinin dört dönem gecikmeli değerlerini içermektedir. Böylelikle geçmiş büyüme dönemlerinin cari büyüme üzerindeki etkisini ölçerek büyümenin sürdürülebilirliğinin kontrol edilmesi amaçlanmaktadır. Otoregresif süreç ile bir iktisadi değişkenin geçmişte aldığı değerlerin içerdiği bilgi yardımıyla, değişkenin gelecekteki değerleri hakkında çıkarım yapılabilmektedir.

GSYiH büyüme denklemi para politikası asimetrisinin varlığını incelemek amacıyla, para politikası şoku göstergesi olan Faiz değişkenini de içermektedir. Para politikası şokları bankalar arası gecelik faiz oranları ile ölçülmüştür. Friedman (1961)'e göre para politikasının reel etkileri üç ila altı aylık bir dönem sonrasında ortaya çıkmaktadır. Bu nedenle Faiz değişkeni ekonometrik modele bir dönem gecikmeli değeri ile eklenmiştir. Son olarak, konjonktür karşıtı iktisat politikası literatürü dış ticarete ve dışa bağımlılığa sıklıkla atıfta bulunduğu için Kur değişkeni modele kontrol değişkeni olarak eklenmiştir. Tahminlenmiş olan MS(2)-AR(4) modeline ait bulgular

\begin{tabular}{|c|c|c|c|c|}
\hline $\begin{array}{l}\text { Bağımlı Değişken: } \\
\text { Gsyih }\end{array}$ & Parametre & Katsayı & Std.Hata & p-değeri \\
\hline Kur & $\theta$ & -15.59 & 7.19 & $0.03 * *$ \\
\hline Gsyih $_{\mathrm{t}-1}$ & $\gamma^{(1)}$ & -0.03 & 0.08 & 0.66 \\
\hline Gsyih $_{t-2}$ & $\gamma^{(2)}$ & -0.14 & 0.08 & $0.07 *$ \\
\hline Gsyih $_{t-3}$ & $\gamma^{(3)}$ & 0.03 & 0.07 & 0.67 \\
\hline Gsyiht-4 $_{\mathrm{t}}$ & $\gamma^{(4)}$ & 0.08 & 0.07 & 0.29 \\
\hline \multicolumn{5}{|l|}{ Daralma Rejimi } \\
\hline Faizt-1 & $\beta_{0}$ & -0.95 & 2.61 & 0.71 \\
\hline Sabit Terim & $\alpha_{0}$ & -3.38 & 0.74 & $0.00 * * *$ \\
\hline \multicolumn{5}{|l|}{ Genişleme Rejimi } \\
\hline Faizt-1 & $\beta_{1}$ & -5.04 & 1.62 & $0.02^{* *}$ \\
\hline Sabit Terim & $\alpha_{1}$ & 1.82 & 0.25 & $0.00 * * *$ \\
\hline
\end{tabular}
Tablo 5'de raporlanmıştır:

Tablo 5: MS(2)-AR(4) Modeli Tahmin Sonuçları

$*, * *$ ve ${ }^{* *}$ sırasıyla $\% 10, \% 5$ ve $\% 1$ düzeyinde anlamlılı̆ı ifade etmektedir. 
Tahmin sonucu elde edilen sabit terim katsayıları, " 0 " indisiyle ayrıştırılmış olan rejimin daralma rejimi, "1" indisiyle ayrıştırılmış olan rejimin ise genişleme rejimi olduğunu göstermektedir. Modelde yer alan sabit terim katsayıları, bağımlı değişkenin GSYiH büyümesi olması nedeniyle, büyüme ve daralma dönemlerindeki ortalama ekonomik büyüme değerleri hakkında bilgi vermektedir. Buna göre Türkiye ekonomisi büyüme rejiminde iken ortalama \%1.82 büyümüş, daralma rejiminde ise ortalama \%3.38 oranında küçülmüştür. Her iki parametre de en yüksek anlamlılık düzeyi olan \%1 seviyesinde anlamlıdır. Ayrıca, her iki rejim için hesaplanmış olan standart hata değerleri ayrı ayrı incelendiğinde, Türkiye ekonomisinin genişleme dönemlerindeki ortalamadan sapmalarının daha az olduğu, dolayısıyla bu dönemlerin daha istikrarlı oldukları görülmektedir.

Konjonktür karşıtı para politikası uygulamasına göre faiz oranları, ekonomik büyüme ile aynı yönde seyretmelidir. Ekonominin genişlediği dönemlerde daraltıcı, ekonominin durgunlaştığı dönemlerde ise genişletici para politikası uygulanarak ekonomik istikrar desteklenmelidir. Ancak Şekil 1 üzerinde de görülebileceği üzere Türkiye' de faiz-büyüme ilişkisi birbirleri ile ters yönlüdür. Türkiye Ekonomisinin daraldığı dönemlerde politika faizi düşürülememiş, aksine arttırılmıştır. Dış finansman ihtiyacı, ara malları ve nihai mallardaki dışa bağımlılık gibi faktörler Türkiye gibi gelişmekte olan piyasa ekonomilerinin, konjonktür karşıtı politika geliştirmelerini güçleştirmektedir. Bu ters etki ise, döviz kuru vasıtasıyla ortaya çıkmaktadır. Bu nedenle döviz kuru MS(2)-AR(4) modeline bu ters etkinin sınanması ve ihmal edilmiş değişken sorunundan kaçınılması amacıyla kontrol değişkeni olarak eklenmiştir. Analiz bulgularına göre Kur değişkeni istatistiksel olarak \%5 düzeyinde anlamlıdır. İktisadi teoriye göre döviz kuru ile toplam iktisadi faaliyet arasında pozitif yönlü ilişki mevcuttur. Bu ilişkiye göre döviz kurunda meydana gelecek artış, ihraç mallarının nispi fiyatlarını düşürerek ihracatı ve toplam talebi arttırmakta, ithal mallarının nispi fiyatını ise arttırarak ithalatı ve dolayısıyla sızıntıları azaltmaktadır. Ancak ekonometrik analiz sonucu elde edilen bulgular, döviz kuru ile ekonomik büyüme arasında ters yönlü bir ilişkinin varlığına işaret etmektedir. Buna göre, kurda meydana gelecek olan 1 birimlik artış GSYiH büyümesini 15 birim azaltmaktadır. Bu ilişkinin sebebinin daha önce de bahsedildiği, üzere dış ülkelere finansmanda, üretimde ve tüketimde olan ekonomik bağımlılıktan kaynaklandığı iddia edilebilmektedir. Kurda meydana gelen artışlar üretimin, tüketimin ve yabancı sermayenin maliyetini arttırarak büyümeyi yavaşlatmaktadır. Bu bulgu Alp (2013) ile tutarlıdır.

Tahminlenmiş olan MS(2)-AR(4) modeli bulguları, para politikası ölçüsü olan Faiz değişkeninde meydana gelecek olan \%1 düzeyindeki artışın, GSYiH büyümesini ekonominin daralma rejiminde $\% 0.95$, ekonominin genişleme rejiminde ise \%5.04 oranında azaltacağı görülmektedir. Elde edilmiş olan bulgular iktisadi teoriler ile uyumludur. İktisat teorisine göre faiz oranındaki artış, parasal aktarım mekanizması vasıtasıyla büyümeyi yavaşlatmaktadır. Faiz değişkeninin iktisadi rejimlere göre elde edilmiş olan tahmin katsayıları incelendiğinde, ekonominin genişleme döneminde uygulanan para politikası şoklarının, ekonominin daralma döneminde uygulanan para politikası şoklarına nazaran daha güçlü olduğu görülmektedir. Faiz değişkeni, ekonominin genişleme rejiminde \%5 seviyesinde anlamlıyken, daralma rejiminde istatistiksel olarak anlamsız bulunmuştur. Elde edilen sonuçlar literatürdeki çeşitli çalışmalar ile tutarlıdır. Morgan (1993), negatif parasal şokların toplam çıktıyı azalttığını, pozitif parasal şokların ise reel etkisi olmadığını iddia etmektedir. Benzer şekilde Shen vd. (2016), merkez bankalarının enflasyonu kontrol yeteneğinin, büyümeyi etkileyebilme yeteneğinden daha yüksek olduğunu öne sürmektedir. Ülke ve Berument (2015) Türkiye Ekonomisi üzerinde yaptıkları çalışmada, sıkı para poli- 
tikasının gevşek para politikasından daha etkili olduğu sonucuna varmışlardır. Literatürde, genişleme dönemlerinde uygulanan para politikalarının, daralma dönemlerinde uygulanan para politikalarından daha etkili sonuçlar verdiğini gösteren pek çok çalışma mevcuttur (bkz. Tenreyro ve Thwaites (2016), Rhee ve Rich (1995), Kato vd. (1999) ve Zakir ve Malik (2013)).

Şekil 1: Türkiye Ekonomisinde ekonomik büyüme ve faiz oranlarının genel görünümü

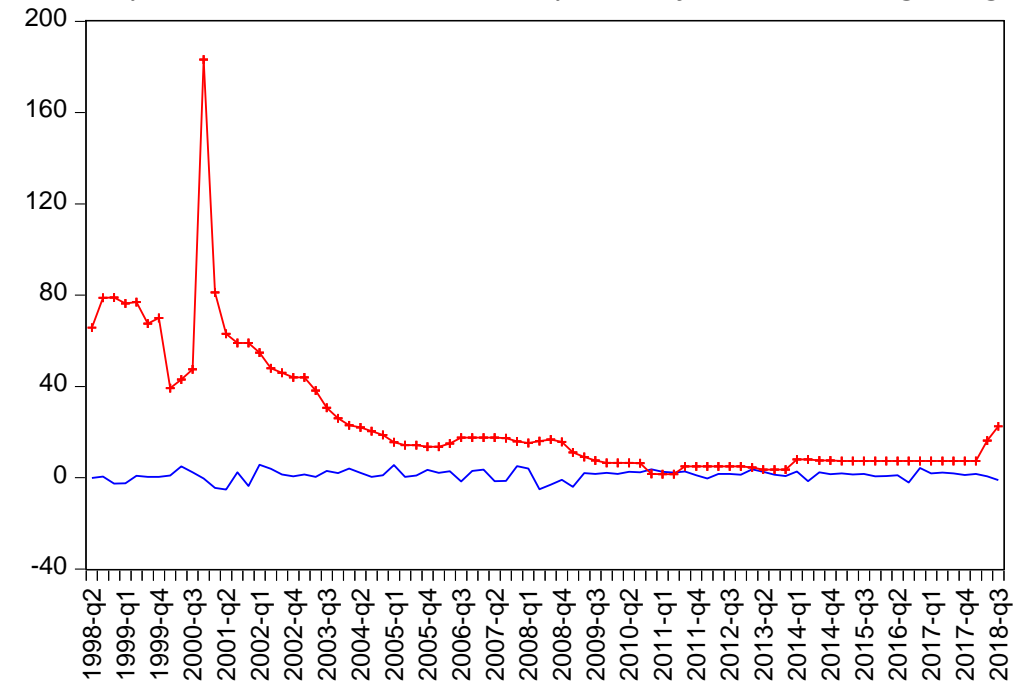

$$
\text { Büyüme Türkiye } \uparrow \text { Faiz Türkiye }
$$

(Kaynak: OECD)

Markov rejim değişimi modelinde gözlemlenemeyen durum değişkeni $s_{t}$, zamanda kesikli değerler alabilen bir Markov zinciri ile modellenebilmektedir. Bu modelleme durum değişkeninin rassal davranışlarının anlaşılmasına yardımcı olmaktadır ve rejim geçiş olasılıkları matrisi olarak adlandırılmaktadır. Rejim geçiş olasılıkları matrisi Tablo 6 'da raporlanmıştır.

\section{Tablo 6: Rejim Geçiş Olasılıkları Matrisi}

$$
P=\left[\begin{array}{ll}
P_{00} & P_{01} \\
P_{10} & P_{11}
\end{array}\right]=\left[\begin{array}{ll}
0.49 & 0.51 \\
0.05 & 0.95
\end{array}\right]
$$

Rejim geçiş olasılıkları matrisine göre, Türkiye ekonomisi cari dönemde daralma rejimindeyken, izleyen dönemde ekonominin daralma rejiminde devam etme olasılığı $P_{00}=0,49$ 'dur. Daralmayı izleyen dönemde ekonominin genişleme rejimine geçiş olasılığı ise $\mathrm{P}_{01}=0.51$ değerini almaktadır. Ekonominin genişleme döneminden daralma dönemine geçiş olasılığı $\mathrm{P}_{10}=0,05$ iken cari dönemde genişleme rejiminde olan Türkiye ekonomisinin takip eden dönemde genişleme rejiminde devam etme olasılığı $\mathrm{P}_{11}=0,95$ olarak bulunmuştur. $\mathrm{P}_{11}$ değeri Türkiye Ekonomisinin hızıı büyüyen dinamik yapısıyla uyumludur. Mevcut rejimin devam etme olasılıklarını gösteren $P_{00}$ ve özellikle de $P_{11}$ yüksek değerler almışlardır. Elde edilen test bulguları Türkiye ekonomisinde özellikle de genişleme dönemlerinde konjonktürel kalııılık, bir başka deyişle devamlılık olduğunu göstermektedir.

\section{Sonuç ve Öneriler}

İktisadi dalgalanmaların yayılma etkisi, Türkiye gibi yükselen piyasa ekonomilerinin gidişatı hakkında önemli bilgiler vermektedir. İktisat yazınında iktisadi dalgalanmaların birlikte hareket ettiği vurgulanarak $\mathrm{ABD}$ gibi büyük ekonomilerde ortaya çıkan şokların dünyanın geri kalanında 
yıkıcı etkiler yaratabildiği iddia edilmektedir. Ülkeler kendi iç sorunlarını çözmeye yoğunlaşarak yabancı ekonomilerden gelebilecek şoklara karşı önlem almakta geciktiği zaman dış dünyadan gelen bir dalganın etkisinin daha yıkıcı bir hal alabilmektedir.

Para politikası literatürü incelendiğinde, para politikası ile ekonomik büyüme etkileşimi sıklıkla incelenmiş ancak analizde genellikle doğrusal yaklaşımlar tercih edilmiştir. Bu yaklaşımlar, para-üretim ilişkisini, ekonominin içerisinde bulunduğu konjonktürel koşulları gözetmeksizin açıklamaktadır. Öte yandan para politikasının ekonominin genişleme ve daralma dönemlerindeki etkisinin aynı olup olmadığı, bir başka deyişle doğrusal olup olmadığı, uzun süredir makro iktisatçılar tarafından tartışılmaktadır. Bu hususun aydınlatılması, uygulanan para politikasının başarısı için büyük önem taşımaktadır. Örneğin bir ekonomik sistemde gevşek para politikasının ekonomik durgunluk üzerinde ancak sınırlı etki meydana getirebildiği önceden biliniyorsa, parasal otoriteler durgunluk zamanlarında gerekli olan genişletici etkinin yaratılabilmesi için farklı önlemler alabilecektir. Bu nedenle bu çalışmanın öncelikli amacı, uygulanan para politikasının ekonominin genişleme ve daralma fazlarına girip çıktığı dönemlerde reel çıktı üzerinde asimetrik bir etkiye sahip olup olmadığını araştırmaktır. Çalışmanın ikinci öncelikli amacı ise, Türkiye Ekonomisine gelen dış şokları ölçmektir. Bu bağlamda, iktisadi dalgalanmaların uluslararası yayılımının anlaşılması, geçmişte yaşananlardan ders çıkarılması, ülkenin iktisadi durumunun gelecek dönemlerde ne şekilde olabileceğinin tahmin edilmesi ve koşullara uygun iktisadi politikaların geliştirilebilmesi açısından faydalı olabilecektir.

Yayılma tablosundan elde edilen bulgular, uluslararası iktisadi dalgalanmaların yayılımının en önemli kaynaklarının ABD, İngiltere, Almanya, Japonya, Güney Kore ve İspanya gibi sanayileşmiş ekonomiler olduğunu göstermektedir. Bu bulgular, sanayileşmiş ülkelerin dünya ekonomisine yön verdiğini ima eden lokomotif hipotezini desteklemektedir. Yayılım endeksi bulgularına göre, Türkiye ekonomisini etkileyen iktisadi şokların \%48'i iktisadi dalgalanmaların uluslararası yayılımından kaynaklanmaktadır. Bu bağlamda, bu ülkelerin iktisadi koşullarının, Türkiye ekonomisi için bir öncü gösterge niteliğinde olabileceği iddia edilebilir.

Markov rejim değişim modeli ile iktisadi rejimlere göre elde edilmiş olan faiz değişkeni tahmin katsayıları incelendiğinde, ekonominin genişleme döneminde uygulanan para politikası şoklarının, ekonominin daralma döneminde uygulanan para politikası şoklarına nazaran daha güçlü olduğu görülmektedir. Faiz değişkeni, ekonominin genişleme rejiminde \%5 seviyesinde anlamlıyken, daralma rejiminde istatistiksel olarak anlamsız bulunmuştur. Bu bulgular, parasal şokların ekonomilerin daralma dönemlerinde daha güçlü etkiler yaratacağını ifade eden arz yönlü para politikası asimetrisi teorileri ile çelişmektedir. Öte yandan, söz konusu bulgular Keynes'e atıfta bulunan ve ekonomi zayıf olduğunda, para politikasıyla yapılabilecek pek bir şeyin olmaması şeklinde ifade edilen ipi çekme teorisi ile büyük benzerlik göstermektedir. Ancak para politikası asimetrisi literatürü incelendiğinde, sanayileşmiş ülkelerde uygulanan parasal şokların, ekonomilerin daralma dönemlerinde daha etkin sonuç verdiği görülmektedir. Bu bulgular para politikası ile ekonominin zayıf olduğu dönemlerde bile güçlü sonuçlar elde edilebileceğini göstermektedir.

Öte yandan ipi çekme teorisi, likidite tuzağı kavramı üzerine kurulmuştur. Bir başka deyişle faiz oranları mümkün olan en düşük düzeydedir. Bu nedenle ekonominin zayıf olduğu dönemlerde genişletici para politikalarıyla faizi daha da düşürmek mümkün değildir. Ancak Türkiye Ekonomisinde faiz oranları kriz dönemlerinde düşmemekte, aksine yükselmektedir (bkz. Şekil 1). Bu sebeple, Türkiye Ekonomisi için para politikası asimetrisini ipi çekme teorisi ile de açıklamak çok mümkün değildir. 
Genel olarak döviz kuru ile toplam iktisadi faaliyet arasında pozitif yönlü ilişki mevcuttur. Bu ilişkiye göre döviz kurunda meydana gelecek artış, ihraç mallarının nispi fiyatlarını düşürerek ihracatı ve toplam talebi arttırmakta, ithal mallarının nispi fiyatını ise arttırarak ithalatı ve dolayısıyla sızıntıları azaltmaktadır. Ancak ekonometrik analiz sonucu elde edilen bulgular, döviz kuru ile ekonomik büyüme arasında ters yönlü bir ilişkinin varlığına işaret etmektedir. Bu bulgu, Türkiye ekonomisi için elde edilmiş olan para politikası asimetrisi bulguları ile birleştirildiğinde ortaya çok önemli sonuçlar çıkmaktadır. Parasal otoriteler kısa vadeli nominal faiz oranlarını, merkez bankası tepki fonksiyonları ile ayarlamaktadırlar ve bu fonksiyonun temelinde Taylor kuralı vardır. Taylor kuralı ise özünde, rüzgâra karşı durmak olarak nitelendirilebilecek konjonktür karşıtı para politikasını ifade etmektedir. Gelişmiş ülkeler genel olarak konjonktür karşıtı para politikası uygulamakta, ekonomi yavaşladığında gevşek, ekonomi hızlandığında ise sıkı para politikası uygulamaktadırlar. Aksine, gelişen piyasa ekonomilerinde uygulanan para politikaları genellikle konjonktür yanlısı niteliktedir. Bir başka deyişle, gelişen piyasa ekonomilerinde uygulanan makro iktisadi tedbirler çoğunlukla iktisadi dalgaları güçlendirmekte, güneşli günleri kavurucu sıcağa, yağmurlu günleri ise şiddetli sağanak yağışlara dönüştürmektedir. Parasal otoriteler, bu sürecin sonunda önemli bir strateji olan konjonktür karşıtı para politikasını uygulayamamakta ve ekonomik istikrarsızlık ile etkin bir şekilde mücadele edememektedirler.

Ancak gelişen piyasa ekonomilerinde, konjonktür karşıtı para politikasının terkedilerek konjonktür yanlısı para politikasının uygulanması bir tercihten ziyade bir zorunluluk halindedir. Enflasyonist, üretimsel ve finansal koşullar parasal otoriteleri konjonktür yanlısı politikalar uygulamaya zorlamaktadır. Bu noktada, bu koşulların ortaya konularak bunların önüne geçilmesini sağlayacak politikaların geliştirilmesi, daha müreffeh bir toplum yaratmanın yolunu açabilecektir. Bu amaçla, literatür derinlemesine araştırılmış ve parasal otoritelerin konjonktür karşıtı para politikası uygulamasını engelleyen koşullar saptanmıştır ve bu doğrultuda politika önerileri sunulmuştur. Bu koşullar genel olarak üretimde, tüketimde ve finansmanda dış bağımlııktan kaynaklanmaktadır ve etkisini döviz kuru üzerinden göstermektedir. Örneğin Türkiye gibi finansal kısıtları ve yabancı para cinsinden borçluluğu yüksek olan bir ekonomide, parasal otoriteler yerel paranın değerini korumak için daralma rejiminde olsalar bile faiz artırımı yoluna gidebilmektedirler. Söz konusu koşullar; dış borç, bilanço etkisi, ara mallarında/nihai mallarda dışa bağımıılı, uluslararası sermaye hareketliliği, mali disiplin ve güven faktörü şeklindedir.

Hızlı büyüyen genç bir ekonomi olan Türkiye Ekonomisinin finansman ihtiyacı da büyüme hızıyla paralel olarak yüksektir. Yetersiz finansal kalkınmışlık, düşük düzeyde finansal okuryazarlık ve yetersiz tasarruf düzeyi gibi nedenlerle finansman ihtiyacı iç piyasadan karşılanamamaktadır ve yatırımlar dış borç ile finanse edilmektedir. Bu durum uluslararası kredi piyasasına kısıtlı erişim, kırılgan bir finansal sistem ve yetersiz finansal derinlik gibi unsurlarla birleştiğinde parasal otoriteleri konjonktür yanlısı politika uygulamaya zorlamaktadır. Böylelikle, ekonominin ihtiyacı olan finansman ihtiyacının karşılanabilmesi amacıyla kötü ekonomik koşullarda dahi faiz artırımı yoluna gidilebilmektedir. Bununla birlikte dış borcun başarılı bir şekilde yönetilememesi, iktisadi sorunların derinleşmesine yol açabilmektedir. Ekonomik krizler ile döviz kuru arasındaki etkileşim incelendiğinde, Türkiye gibi yabancı para cinsinden borçların yüksek düzeyde olduğu ekonomilerde gerçekleşen ani kur artışlarının yıkıcı olduğu görülmektedir. Sonuç olarak, parasal otoriteler bu yıkımdan kaçınmak amacıyla ekonomik durgunluk dönemlerinde sıkı para politikası uygulayarak kuru dizginlemeye çabalamaktadırlar.

Bu sürecin altında yatan sebeplerden birisi "Temel Günah" olarak isimlendirilmektedir ve ülkelerin uluslararası piyasalardan yerel paraları ile borçlanamaması ve/veya iç piyasadan sabit 
faiz ile uzun vadeli finansman kullanamaması olarak tanımlanmaktadır. Döviz cinsinden borçlanmaya dair en ciddi sorun, para birimi uyumsuzluğu olarak adlandırılan olgudur ve varlıklarla yükümlülükler arasındaki uyumsuzluğu ifade etmektedir. Döviz kurunun artması durumunda firmalar, yabancı para cinsinden borçlarını ödemekte zorluk yaşamaktadırlar. Bu durum ise, genellikle ekonomik darboğaz anlarında yaşanmaktadır ve merkez bankalarının ulusal parayı korumak amacıyla faiz artırımı yapması ile sonuçlanmaktadır. Uyumsuzluk ve temel günahtan kaynaklanan sorunların önüne geçilebilmesi amacıyla finansal kalkınmışlığın desteklenmesi ve iç piyasadan borçlanma imkânlarının arttırıması gerekmektedir. Bununla birlikte ulusal paranın değer kaybetmesi, ülkeye dış ticaret avantajı kazandırarak artan ihracat vasıtasıyla ekonomik büyümeyi arttırabilmektedir. Öte yandan ulusal paranın değer kaybı, firmaların kısa dönemli ve yabancı para cinsinden yükümlülükleri vasıtasıyla firma bilançolarında bozulmaya sebep olmakta, firmaların net değerlerini dolayısıyla da yatırımlarını ve ekonomik büyümeyi olumsuz etkilemektedir. Firmaların kısa dönemli ve yabancı para cinsinden yükümlülüklerinin toplam yükümlülükleri içerisindeki payının çok büyük olduğu gelişen piyasa ekonomilerinde, kur artışının neden olduğu negatif bilanço etkisi, pozitif dış ticaret avantajı etkisinden büyük olmaktadır. Türkiye Ekonomisinde de TL'de meydana gelen değer kaybının yarattığı negatif bilanço etkisi, pozitif ticaret avantajı etkisini bastırmaktadır ve net etki negatif olmaktadır. Hedging metotları ya da türev ürünler kullanılarak, kur vb. nedenlerle ortaya çıkabilecek risklere karşı güvence sağlamak mümkündür.

Borç dolarizasyonu ve firmaların negatif bilanço etkisi sonucu bir uygulama zorunluluğu olarak ortaya çıkan konjonktür yanlısı para politikası, döviz kurunu kontrol altına alarak ortaya çıkabilecek olumsuzlukları asgari düzeye indirmeyi amaçlamaktadır. Buraya kadar anlatılanlar, finansmandaki dışa bağımlılık ile ilgilidir ve döviz talebini etkileyerek döviz kurunu, kur vasıtasıyla da dış borcun TL cinsinden değerini ve firmaların bilançolarını etkilemektedir. Döviz talebini ve döviz kurunu etkileyen dolayısıyla da konjonktür yanlısı politikaların uygulanmasını zorunlu kılan bir başka etmen ise, nihai mallardaki ve hatta ara mallarındaki dışa bağımlılıktır. Türkiye Ekonomisi gelişmiş sanayisi ve dinamik yapısına rağmen sermaye yoğun pek çok malın ithalatçısı durumundadır. Bununla birlikte çok zengin doğal kaynaklarına rağmen, yenilenebilir enerji kaynaklarından yeterince yararlanamamakta ve enerji ithalatı için ciddi bir bütçe ayırmak durumunda kalmaktadır. Yakın zamana kadar bir tarım ülkesi konumunda olan Türkiye, günümüzde kendisine yeterli olabilme özelliğini yavaş yavaş kaybetmekte, tarımsal ürünlerde bile ithalat yapmaktadır. Buna ilave olarak, iç piyasada üretilen mallarda kullanılan ara mallarında bile dışa bağımlılık ciddi düzeylere ulaşmıştır. Günümüz Türkiye'sinde $100 \$$ değerindeki ihracat için yaklaşık 70\$ değerinde ara malı ithalatı yapılması gerekmektedir. Bu durum da, döviz kuru dolayısıyla da yabancı para cinsinden borçların TL değeri ve firma bilançoları üzerinde baskı yaratarak parasal otoriteleri içinden çıkılması güç durumlara sokmaktadır. Bu bağlamda, Türkiye Ekonomisinin üretimdeki ve tüketimdeki dışa bağımlılığını azaltacak önlemler, etkin döngüsel para politikalarının uygulanabilmesine de zemin hazırlayacaktır.

Altyapısı yeterince geliştirilemeyen kurumlar ile uygulanan politikalara güvenilmemesi, gelişmekte olan piyasa ekonomilerinin konjonktür karşıtı para politikaları uygulamalarını engelleyebilmektedir. Kurumlara duyulan güvenin düşük düzeyde olması, yabancı yatırımcının iktisadi karar alma sürecini etkilediği gibi, yurtiçi yerleşiklerin de kararlarını etkilemektedir. Örneğin, yurtiçi yerleşiklerde merkez bankasının enflasyon ile yeterli düzeyde mücadele etmediği şeklinde bir algının oluşması, iç piyasada ulusal paranın terk edilmesine ve dolarizasyona neden 
olabilmektedir. Artan döviz talebi ise, kur üzerinde baskıya neden olarak para politikasının etkinsizleşmesine yol açacaktır. Bu bağlamda kurumsal altyapının geliştirilmesi, ülke ekonomisine duyulan güveni de destekleyecektir. Güven faktörü, para politikası asimetrisi açısından ele alındığında, bireylerin ve firmaların güven seviyelerinin konjonktürün farklı dönemlerinde çeşitlilik gösterebildiğine dikkat edilmektedir. Hane halkları ve firmaların ekonominin genişleme döneminde iyimser, daralma döneminde ise kötümser olmaları beklenir. Bununla birlikte hane halkları ve firmaların ekonominin daralma fazındaki kötümserlik düzeyinin, ekonominin genişleme fazındaki iyimserlikten daha yüksek olması, uygulanan para politikasının asimetrik etkiler yaratabilmesine yol açacaktır. Yukarıdaki örnek, ekonominin genişleme döneminde uygulanan daraltıcı para politikasının, ekonominin daralma döneminde uygulanan genişletici para politikasından daha etkin sonuçlar doğuracağını ifade etmektedir ve bu makalenin ekonometrik analiz bulguları da bu doğrultudadır. Genişletici para politikasının etkinsizliğini kötümserlik yardımıyla açıklamak için ise, "bir atı suya götürebilirsiniz ancak ona zorla su içiremezsiniz" benzetmesi kullanılmaktadır. Bu benzetme piyasadaki likidite ile yatırımlar arasında birebir ilişki olmadığı anlamına gelmektedir. Biraz açıklamak gerekirse, durgunluk döneminde ekonomiyi canlandırmak amacıyla piyasaya likidite enjekte edebilir ya da faiz oranlarını düşürebilirsiniz ancak, bireyleri o fonu kullanıp yatırım yapmaya zorlayamazsınız. Bu durum ise, merkez bankasının beklentileri etkilemedeki, dolayısıyla da karar alma sürecindeki başarısızlığını göstermektedir. Politik baskının olmadığı bağımsız merkez bankacılığı ile hesap verebilir ve şeffaf para politikası yürütülmesi, ekonomide güven duygusunun tesis edilmesi için gereklidir. Ancak tüm bireyler merkez bankasının koyduğu hedeflere ulaşabileceğine ve ekonomik istikrarın gelecekte beklenen düzeyde olacağına inandığı takdirde iktisadi sistem en iyi şekilde işleyecektir.

Uluslararası iktisadi dalgalanmaların gelişmekte olan ülkelere yayılımı ve bu yayılımın iç piyasadaki makro iktisadi göstergeler üzerinde meydana getirdiği etkiyi inceleyen araştırmalar, genel olarak uluslararası iktisadın açmazı olarak isimlendirilen imkânsız üçleme hipotezini analiz etmektedir. Sermaye hareketlerinin serbest olduğu, cari açığın ciddi oranlara geldiği, yoğun ara ve nihai mal ithalatının gerçekleştirildiği gelişen piyasa ekonomilerinde, uluslararası iktisadi dalgalanmalar çeşitli siyasi ve ekonomik sebeplerle iç piyasadaki ekonomik göstergeleri ciddi düzeyde etkileyebilmektedir ve bu etki genellikle döviz kuru vasıtasıyla ortaya çıkmaktadır. Buraya kadar açıklanmış öneriler, öncelikle uluslararası şokların bir bölümünün iç piyasaya aktarılmasını önleyerek ekonomik istikrar sağlayıcı niteliktedir. Bu politikalar uygulandığı takdirde politika yapıcılar, politika açmazlarının yarattığı kaotik durumdan kendilerini koruyabilecek ve sadece iç piyasada ortaya çıkan olumsuzlukları önlemeye yönelik politika geliştirmeye odaklanabileceklerdir. Bununla birlikte burada önerilen politikalar üretimde, tüketimde ve finansmanda dışa bağımlıığın azaltılmasına yöneliktir. Böylelikle iktisat politikasının önemli bir kolu olan para politikası, ekonomik istikrarın sağlanması için daha etkin bir şekilde kullanılabilecektir. 


\section{Eskişehir Osmangazi Üniversitesi IïB Dergisi}

\section{Kaynaklar}

Agénor, Pierre-Richard (2001), "Asymmetric Effects of Monetary Policy Shocks",World Bank Working Paper.

Akın, Çiğdem (2007), "Multiple Determinants of Business Cycle Synchronization”, SSRN Electronic Journal, 1-57.

ALP, Bengü (2013), "Türkiye'deki Reel Sektör Firmalarında Borç Dolarizasyonu ve Reel Kur Değiş̧imlerinin Bilanço Etkisi”, TCMB Uzmanlık Yeterlilik Tezi.

Antonakakis, Nikolaos; Badinger, Harald (2014), "International Business Cycle Spillovers since the 1870s." Applied Economics, Vol. 46, No. 30: 3682-94.

Antonakakis, Nikolaos; Breitenlechner, Max; Scharler, Johann (2015), "Business Cycle and Financial Cycle Spillovers in the G7 Countries", Quarterly Review of Economics and Finance, Vol. 58: 154-162.

Antonakakis, Nikolaos; Chatziantoniou, loannis; Filis, George (2013), "Business Cycle Spillovers in the EU15: What Is the Message Transmitted by the Periphery?", Member Research Papers, Euro Area Business Cycle Network.

Antonakakis, Nikolaos; Chatziantoniou, loannis; Filis, George (2016), "Business Cycle Spillovers in the European Union: What Is the Message Transmitted to the Core?", Manchester School, Vol. 84, No. 4: 437-481.

Barışık, Salih; Çevik, Emrah İsmail (2008), "Türkiye'de İşsizlik Histerisinin Yapısal Kırılma ve Güçlü Hafıza Modellemesi Ile Sektörel Analizi", TisK Akademi, Vol. 3, No. 6: 66-87.

Barnichon, Regis; Matthes, Christian; Sablik, Tim (2017), "Are the Effects of Monetary Policy Asymmetric", Richmond Fed Economic Brief, (March), 1-4.

Bayoumi, Tamim; Bui, Trung (2010), "Deconstructing the International Business Cycle: Why Does A US Sneeze Give the Rest of the World a Cold", IMF Working Papers, 1-28.

Biçici, Kevser (2015), “Para Politikası Şoklarının Hâsıla ve Fiyat Düzeyi Üzerindeki Asimetrik Etkileri : Orta Asya ve Balkan Ülkeleri Uygulaması”, Başkent Üniversitesi Sosyal Bilimler Enstitüsü.

Bubák, Vít; Kočenda, Evžen; Žikeš, Filip (2011), "Volatility Transmission in Emerging European Foreign Exchange Markets", Journal of Banking \& Finance, Vol. 35, No. 11:2829-2841.

Çolpan Nart, Ela (2013), "Uluslararası Finansal Krizlerin Temel Kaynakları: Yabancı Para Cinsinden Borçlanma ve Temel Günah", Dokuz Eylül Üniversitesi Sosyal Bilimler Enstitüsü.

Cover, James Peery (1992), “Asymmetric Effects of Positive and Negative Money-Supply Shocks”, The Quarterly Journal of Economics, Vol. 107, No. 4: 1261-1282.

Davig, Troy; Doh, Taeyoung (2013), "Monetary Policy Regime Shifts and Inflation Persistence", The Review of Economics and Statistics, Vol. 96, No. 5: 862-875.

Dellas, Harris (1986), "A Real Model of the World Business Cycle", Journal of International Money and Finance, Vol. 5, No. 3: 381-394.

Dickey, David A.; Fuller, Wayne A. (1979), "Distribution of the Estimators for Autoregressive Time Series With a Unit Root", Journal of the American Statistical Association, Vol. 74, No. 366: 427-431.

Dickey, David A.; Fuller, Wayne A. (1981), "Likelihood Ratio Statistics for Autoregressive Time Series with a Unit Root", Econometrica, Vol. 49, No. 4: 1057-1072.

Diebold, Francis X.; Yılmaz, Kamil (2009), “Measuring Financial Asset Return and Volatility Spillovers, with Application to Global Equity Markets", Economic Journal, Vol. 119, No. 534: 158-171.

Diebold, Francis X.; Yılmaz, Kamil (2013), "Measuring the Dynamics of Global Business Cycle Connectedness", PIER Working Paper, No: 13-070.

Doan, T. (2010), "RATS programs to replicate Diebold and Yilmaz EJ 2009 spillover calculations", Statistical Software Components RTZ00044, Boston College Department of Economics.

Dolado, J. Juan; Dolores, Ramón María (2001) “An Empirical Study of the Cyclical Effects of Monetary Policy in Spain (1977-1997)”, Investigaciones Económicas, Vol. 25, No. 1: 3-30.

Doyle, Brian M.; Faust, Jon (2005), "Breaks in the Variability and Comovement of G-7 Economic Growth", The Review of Economics and Statistics, Vol. 87, No. 4: 721-740.

Du, Jiangze; Yu, Runfang; Lai, Kin Keung (2018), “Identification and Prediction of Currency Crisis: Markov SwitchingBased Approach", Singapore Economic Review, 1850002.

Ergeç, Etem Hakan (2009a), "Para Politikasi Şoklarinin Asimetrik Etkileri”, Eskişehir Osmangazi Üniversitesi Sosyal Bilimler Dergisi, Vol. 10, No. 2: 65-90. 
Ergeç, Etem Hakan (2009b), "Türkiye Ekonomisinde Pozitif Ve Negatif Para Politikası Şoklarının Asimetrik Etkileri", Dumlupınar Üniversitesi SBE Dergisi, Vol. 23: 333-344.

Fidrmuc, Jarko; Ikeda, Taro; Iwatsubo, Kentaro (2012), "International Transmission of Business Cycles: Evidence from Dynamic Correlations", Economics Letters, Vol. 114, No. 3: 252-255.

Florio, Anna (2004), "The Asymmetric Effects of Monetary Policy", Journal of Economic Surveys, Vol. 18, No. 3: 409426.

Friedman, Milton (1961), "The Lag In Effect of Monetary Policy”, Journal of Political Economy, Vol. 69, No. 5: 447-466.

Gallo, Julie Le; Ertur, Cem (2003), "Exploratory Spatial Data Analysis of the Distribution of Regional per Capita GDP in Europe , 1980 - 1995”, Papers in Regional Science, Vol. 201, No. 2: 175-201.

Garcia, Rene; Schaller, Huntley (2002), “Are the Effects of Monetary Policy Asymmetric?", Economic Inquiry, Vol. 40, No. 1: 102-119.

Granger, Clive W. J.; Newbold, Paul (1974), "Spurious Regressions in Econometrics", Journal of Econometrics, Vol. 2, No. 2: 111-120.

Gregory, Allan W.; Head, Allen C.; Raynauld, Jacques (1997), "Measuring World Business Cycles", International Economic Review, Vol. 38, No. 3: 677-701.

Hamilton, James D. (1989), "A New Approach to the Economic Analysis of Nonstationary Time Series and the Business Cycle", The Econometric Society, Vol. 57, No. 2: 357-384.

Höppner, Florian; Melzer, Christian; Neumann, Thorsten (2008), “Changing Effects of Monetary Policy in the US - Evidence from a Time-Varying Coefficient VAR", Applied Economics, Vol. 40, No. 18: 2353-2360.

Ibrahim, Mansor H. (2003), "International Disturbances and Domestic Macroeconomic Fluctuations in Malaysia", ASEAN Economic Bulletin, Vol. 20, No. 1: 11-30.

Kakes, Jan (1998), "Monetary Transmission and Business Cycle Asymmetry", s.n. (SOM research report No. 98C36), Groningen.

Kandemir Kocaaslan, Özge (2013), "An Empirical Investigation of The U.S. GDP Growth: A Markov Switching Approach", University of Sheffield.

Karras, Georgios (1996a), "Are the Output Effects of Monetary Policy Asymmetric? Evidence from a Sample of European Countries", Oxford Bulletin of Economics and Statistics, Vol. 58, No. 2: 267-278.

Karras, Georgios (1996b), "Why Are the Effects of Money-Supply Shocks Asymmetric? Convex Aggregate Supply or 'Pushing on a String?", Journal of Macroeconomics, Vol. 18, No. 4: 605-619.

Kato, Ryo; Ui, Takashi; Watanabe, Tsutomu (1999), "Asymmetric Effects of Monetary Policy: Japanese Experience in the 1990s", Bank of Japan Working Paper, 99-2, Tokyo.

Korkmaz, Turhan; Zaman, Selin; Çevik, Emrah İsmail (2008), “Türkiye’nin Avrupa Birliği ve Yüksek Dış Ticaret Hacmine Sahip Ülke Borsaları Ile Entegrasyon İlişkisi”, ZKÜ Sosyal Bilimler Dergisi, Vol. 4, No. 8: 19-44.

Kose, Ayhan M.; Otrok, Christopher; Prasad, Eswar S. (2008), "Global Business Cyles: Convergence or Decoupling?", NBER Working Paper Series Global No. 14292

Lenz, Carlos (1997), "Asymmetrie Effects of Monetary Policy in Switzerland", Swiss Journal of Economics and Statistics, Vol. 133, No. 3: 441-454.

Liu, Junlin; Chen, Feier (2018), “Asymmetric Volatility Varies in Different Dry Bulk Freight Rate Markets under Structure Breaks", Physica A: Statistical Mechanics and Its Applications, Vol. 505: 316-327.

Lo, Ming Chien; Piger, Jeremy Max (2005), "Is the Response of Output to Monetary Policy Asymmetric? Evidence from a Regime-Switching Coefficients Model”, Journal of Money, Credit, and Banking, Vol. 37, No. 5: 865-886.

Malone, M. Stokes (2000), "An Investigation of Money Supply Shock Asymmetry Using Disaggregate Data", M.S. Research Paper.

McMillan, David G.; Speight, Alan E. H. (2010), "Return and Volatility Spillovers in Three Euro Exchange Rates", Journal of Economics and Business, Vol. 62, No. 2: 79-93.

Mishkin, Frederic S. (2005), Para Teorisi-Politikası, ed. A. Ç. ve S. Y. Çev. İlyas Işıklar. Eskişehir: Bilim Teknik Yayınevi.

Morgan, Donald P. (1993), "Asymmetric Effects of Monetary Policy", Federal Reserve Bank Of Kansas City Economic Review, Vol. 78: 20-33.

Mumtaz, Haroon; Theodoridis, Konstantinos (2015), "The International Transmission of Volatility Shocks: An Empirical Analysis", Journal of the European Economic Association, Vol. 13, No. 3: 512-533. 


\section{Eskişehir Osmangazi Üniversitesi IïBF Dergisi}

Ravn, Morten O.; Sola, Martin (2004), "Asymmetric Effects of Monetary Policy in the United States", Review, Federal Reserve Bank of St. Louis, 86(Sep): 41-60.

Rhee, Wooheon; Rich, Robert W. (1995), "Inflation and the Asymmetric Effects of Money on Output Fluctuations", Journal of Macroeconomics, Vol. 17, No. 4: 683-702.

Schneider, Martin; Fenz, Gerhard (2011), "Transmission of Business Cycle Shocks between the US and the Euro Area", Applied Economics, Vol. 43, No. 21: 2777-2793.

Shen, Chung Hua; Lin, Kun Li; Guo, Na (2016), "Hawk or Dove: Switching Regression Model for the Monetary Policy Reaction Function in China", Pacific Basin Finance Journal, Vol. 36: 94-111.

Sola, Martin; Spagnolo, Fabio; Spagnolo, Nicola (2007), "Predicting Markov Volatility Switches Using Monetary Policy Variables", Economics Letters, Vol. 95, No. 1: 110-116.

Tenreyro, Silvana; Thwaites , Gregory (2016), "Pushing on a String: US Monetary Policy Is Less Powerful in Recessions", American Economic Journal: Macroeconomics, Vol. 8, No. 4: 43-74.

Thoma, Mark A. (1994), "Subsample Instability and Asymmetries in Money-Income Causality", Journal of Econometrics, Vol. 64: 279-306.

Ülke, Volkan; Berument, M. Hakan (2015), “Asymmetric Effects of Monetary Policy Shocks on Economic Performance: Empirical Evidence from Turkey", Applied Economics Letters, Vol. 23, No. 5: 353-360.

Yılancı, Veli; Tıraşoglu, Muhammed; Arı, Ayşe (2016), “Para Politikası Şoklarının Etkisi: Asimetrik Etki Tepki Fonksiyonu Yaklaşımı", Ekonomik Yaklasim, Vol. 27, No. 100: 131-154.

Yılmaz, Kamil (2009), "International Business Cycle Spillovers", Tüsiad-Koç University Economic Research Forum Working Paper.

Yılmaz, Kamil (2010), "Return and Volatility Spillovers among the East Asian Equity Markets", Journal of Asian Economics, Vol. 21, No. 3: 304-313.

Zakir, Nadia; Malik, Wasim Shahid (2013), "Are the Effects of Monetary Policy on Output Asymmetric in Pakistan?", Economic Modelling, Vol. 32, No. 1: 1-9.

Zhou, Xiangyi; Zhang, Weijin; Zhang, Jie (2012), "Volatility Spillovers between the Chinese and World Equity Markets", Pacific-Basin Finance Journal, Vol. 20, No. 2: 247-270.

Zivot, Eric; Andrews, Donald W. K. (1992), "Further Evidence on the Great Crash, the Oil-Price Shock, and the Unit-Root Hypothesis", Journal of Business and Economic Statistics, Vol. 10, No. 3: 251-270. 


\section{Extended Summary}

\section{International Business Cycle Spillover Effects and Counter-Cyclical Monetary Policy}

The aim of this study is to answer the question whether if economic fluctuations of the foreign economies can be used as a leading indicator for Turkish Economy and develop a monetary policy in line with the characteristics of the economic fluctuations that may occur in the following periods or not. For this purpose, the international spillover of economic fluctuations is measured and state asymmetry of the monetary policy, which is used to investigate effects of monetary policy on different cyclical regimes, namely expansion and contraction, are analyzed. Considering the positive or negative effects of economic contraction in one country on another one, it is of great importance to obtain information about the business cycle spillover of the most developed countries in the world. In another words, this research is aimed to empirically investigate the well-known phrase "When America Sneezes, the World Catches Cold". In this context, understanding the international spillover of economic fluctuations and predicting the future economic situation of the country may be beneficial in terms of developing appropriate economic policies. On the other hand, consideration of asymmetric effects in the process of monetary policy development is of great importance for the effectiveness of the monetary policy. For instance, if the impact of monetary policy is asymmetrical, economists should be aware that the monetary transmission mechanism works differently in different periods of the economic conjuncture.

In the first phase of this study the international spillover of economic fluctuations is investigated via Diebold and Yilmaz (2009) spillover index method and external shocks to Turkey has been estimated. Spillover Index methodology is based on variance decomposition and VAR models derived from the N-variable vector error correction model. In the second phase of the study, the state asymmetry of the monetary policy, which is described as the effects of implemented monetary policies differing according to prevailing economic regimes, namely expansion and contraction, has been tested by Hamilton (1989) Markov Regime Switching method, which gives a different perspective to the economic literature. Hamilton (1989) model can successfully divide discussed time period into the expansion and contraction regimes by predicting the turning points of economic fluctuations.

Monetary aggregates and interest rates are generally used to measure monetary policy actions. However, using monetary aggregates as monetary policy proxy leads to some measuring problems. A one example of these problems is the fact that every change in monetary policy may not be reflected in monetary aggregates. Besides that various monetary aggregates can change in different directions and display contradictory views about the monetary stance. For these reasons interbank interest rates, which is obtained from OECD Database, is used to measure monetary policy reactions in Turkey. In addition to this real GDP growth data is employed to measure the effects of monetary policy on business cycles and growth data is obtained from St. Louis Federal Reserve Bank Fred Database. The real exchange rate, which is obtained from OECD Database, is added to the econometric model as a control variable because studies on counter-cyclical economic policies in emerging markets often refer to foreign trade relations and economic dependence. The data set used in the Markov switching model covers the period of 1998 Q2 and 2018 Q3.

For the spillover index methodology, the monthly industrial production index from the OECD database was preferred. The most important reason for the industrial production index to be preferred for the spillover index is that spillover index methodology performs better with monthly data and the national income accounts are not published monthly. The dataset includes 23 industrialized and emerging countries besides Turkey and covers the period of January 1985 to November 2018.

According to the findings obtained by the Spillover Index Method, 48\% of economic shocks affecting the Turkish Economy caused by international spillovers of economic fluctuations. More specifically the economic fluctuations that occurred in Turkey are originated 12,5\% from South Korea, $8.4 \%$ from US, 6.4\% from Japan, 4.5\% from Greece and $3.2 \%$ from the Spanish Economy's external shocks. According to these results, the economic conditions of these countries are leading indicators for the Turkish Economy. Markov Regime Switching model findings show that Turkish Economy grows $1.62 \%$ on an average in the expansion, shrinks $0.95 \%$ on an average in the contraction and an increase in the exchange rate slows the economic growth in Turkey. Finally obtained econometric evidence shows that The Central Bank of Turkey can bring real effect in expansion regime but not create real impact in the fight against recession.

According to the counter-cyclical monetary policy practice, interest rates should follow the same direction as economic growth. In a nutshell, economic stability should be supported by applying contractionary monetary policy during expansion periods and expansionary monetary policy during recession periods. However, the relationship between interest rate and growth is negative as it can be seen in Figure 1. According to the Figure 1, interest rate is not able to reduce in recessionary periods in Turkey; on the contrary it is increased. In another saying, Turkey conducts pro-cyclical monetary policy along similar lines with other emerging market economies. It can be argued that this pro-cyclical monetary action is originated from economic dependence of Turkey. It is frequently emphasized that economic growth of 


\section{Eskişehir Osmangazi Üniversitesi ïiBF Dergisi}

Turkey is dependent on external sources such as financing, intermediate goods and final goods. In addition to this, economic dependence of Turkey creates an adverse effect and it arises through the exchange rate. For this reason, the exchange rate is added to the econometric model as a control variable to test this adverse effect. According to economic theory, there is a positive relationship between exchange rate and total economic activity. However, the findings obtained from the econometric analysis point to the existence of an inverse relationship between the exchange rate and economic growth. It can be argued that the reason for this relationship is due to the Turkey's economic dependence to foreign countries on financing, production and consumption. Increases in exchange rates slow down growth by increasing the cost of production, consumption and foreign capital. As a consequence of these effects Central Bank of the Republic of Turkey is obliged to conduct contractionary monetary policy to attract foreign capital and appreciate Turkish Lira even in recessionary periods. In conclusion, policy makers in Turkey should closely monitor the world economy. Since recessionary economic movements, in especially industrialized countries, may tends to spillover to Turkey. Additionally, they should take necessary precautions to eliminate Turkey's external dependencies that prevent Turkey to implement counter-cyclical monetary measures. 